\title{
Aboutness and negative truths: a modest strategy for truthmaker theorists
}

\author{
Arthur Schipper $^{1}{ }_{(\mathbb{B}}$
}

Received: 9 May 2016 / Accepted: 27 March 2017 / Published online: 12 April 2017

(C) The Author(s) 2017. This article is an open access publication

\begin{abstract}
A central problem for any truthmaker theory is the problem of negative truths (P-NEG). In this paper, I develop a novel, piecemeal strategy for solving this problem. The strategy puts central focus on a truth-relevant notion of aboutness within a metaphysically modest version of truthmaker theory and uses key conceptual tools gained by taking a deeper look at the best attempts to solve the problem of intentionality. I begin this task by critically discussing past proposed solutions to P- NEG in light of Russell's debate with Demos. This reveals a central difficulty with addressing the problem, specifically that one cannot be committed to incompatibility facts in one's account of negation and of the truth of negative truths. I then present an aboutnessbased version of truthmaker theory. Utilising what I call the strict and full account of aboutness, I extract aboutness-based theories of truth and falsity. I use this machinery to present a promising new strategy for solving P- NEG which does not have the problems of alternative approaches. Finally, I present and respond to some potential objections.
\end{abstract}

Keywords Aboutness - Negative truths · Truthmaker theory $\cdot$ Modesty $\cdot$ Intentionality · Truthmaker maximalism · Russell, Demos, and Meinong

\section{Introduction}

In this paper, I use the aboutness-machinery of a modest version of truthmaker theory to sketch a novel, piecemeal strategy for solving the central problem for any truthmaker theory, namely the problem of negative truths (P- NEG).

Arthur Schipper

schipper.philosophy@gmail.com

1 Institute for Philosophy, Leiden University, 3-4 Reuvensplaats, 2311BE Leiden, The Netherlands 
In Sect. 2, I present P- NEG and discuss past proposed solutions in light of Russell's debate with Demos, which reveals a central difficulty with addressing the problem. In Sect. 3, I discuss Molnar's (2000) presentation of P- NEG, and explain in what sense there is a real distinction between negative and positive. In Sect. 4, I present the bare-bones of the modest, aboutness-based version of truthmaker theory. In doing so, I focus my attention on key aspects of what I call the strict and full account of aboutness and of the theory of intentionality which help us address the problem of intentionality. This allows me to extract aboutness-based theories of truth and falsity. In Sect. 5, I use this machinery to present an aboutness-based strategy for solving P- NEG. Finally, in Sect. 6, I present and respond to some potential objections.

\section{The problem of negative truths and some difficulties for addressing it}

P-NEG is the problem of how exactly truthmaker theory (TT) can account for true negative truthbearers ${ }^{1}$ such as

T1: Pegasus does not exist.

T2: The cat is not on the mat.

T2*: It is not the case that the cat is on the mat. ${ }^{2}$

Given their committment to an asymmetric dependence between truths and reality, TT-ists seem beholden to answer the following two questions: "What does the truth of claims such as T1 and T2 depend on?" and, more specifically, "What are the truthmakers for negative truths?" Neither T1 nor T2 seem to describe a way that the world is, but rather purport to describe a way the world is not. And since T1 and T2 are both true, we seem to have a case where there are truths that do not need truthmakers. If this reasoning is correct, the TT-ist seems to be stuck with a dilemma: either reject

\footnotetext{
1 Throughout this paper, I remain neutral and pluralist as to whether propositions, sentences, token beliefs, or whatever other candidate truthbearers are the right or primary truthbearers. Therefore, I shall speak generally about truthbearers. Just as another example, Mumford (2007: p. 45) is also explicit about his truthbearer- neutrality. I follow Kirkham's (1992: pp. 59-64) "tolerant attitude about truth bearers" (ibid.: p. 59), but remain agnostic about whether "[ $\mathrm{t}]$ he matter is one of choice, not discovery" (ibid.), or whether, as Platts (1997: pp. 33-35, 37-42) argues, the issue is philosophically uninteresting.

2 Even though T1, T2, and T2* are negative truths, by contrast to T1, T2 and T2* are also partially positive since $\mathrm{T} 2$ and $\mathrm{T} 2 *$ are about various parts of the world, namely the cat and the mat. However, $\mathrm{T} 2$ and $\mathrm{T} 2 *$ are still negative truths since they also state that there is not a particular relation of being on between the cat and the mat. A useful passage to consider here is one from Russell (1919: p. 287), in which he writes: "Socrates loves Plato' and 'Napoleon does not love Wellington' are facts which have opposite forms. We will call the form of 'Socrates loves Plato' positive and the form of 'Napoleon does not love Wellington' negative. So long as we confine ourselves to atomic facts [...] the distinction between positive and negative facts is easily made." Russell, thus, obviously has no problem with thinking of such sentences as T2 and T2* as negative even though they also refer to existing objects. In fact, as he makes clear in the passage, sentences of this form are ones in which the distinction between positive and negative are easily made. Further, T2 and T2* display the traditional distinction between internal and external negation. An anonymous reviewer from this journal has kindly informed me that "on the view of many, it is only the latter [i.e. external negations] which would genuinely represent something like a negative fact". What I say in this paper addresses sentences such as $\mathrm{T} 2$ as well as $\mathrm{T} 1$ and $\mathrm{T} 2 *$, even if such truths are not genuinely negative.
} 
Truthmaker Maximalism (Maximalism or T-M), ${ }^{3}$ which states that all truths require truthmakers to make them true, or accept "unsavoury" negative facts, such as Pegasus's non-existence or the cat's not being on the mat, into one's ontology.

This dilemma is very troubling. On the one hand, if one tries to reject T- M, this rejection cannot be arbitrary or ad hoc. ${ }^{4}$ One must have good independent reasons to restrict the scope of truthmaking. And, in the course of one's rejection-strategy, one must not fall into positing unsavoury negative entities of any sort. On the other hand, philosophers have been very reluctant to accept negative beings (e.g. negative facts or negative properties) into the right ontology. Russell (1918, 1919), notoriously, accepts negative facts into his ontology without any hesitation on his part, but admits that there is "a certain repugnance to negative facts" (1918: p. 211), to such an extent that when he argued that there were negative facts, at a lecture in Harvard in 1914, he reports that "it nearly produced a riot" (ibid.). To explain this, he writes,

There is implanted in the human breast an almost unquenchable desire to find some way of avoiding the admission that negative facts are as ultimate as those that are positive. [1919: p. 287; my emphasis]

Besides Barker and Jago (2012) who have recently tried to argue that negative facts can be understood positively, there are hardly any contemporary analytic philosophers ${ }^{5}$

\footnotetext{
3 Most philosophers who take TT seriously consider negative truths, especially negative existentials, to be counterexamples to T- M. See, explicitly, (Bigelow 1988:p. 131), (Cameron 2005: p. 4), (Fox 1987:p. 4), (Lewis 1999 and Lewis 2001), (Linsky 1994: §2), (Mellor 2003:pp. 213-214), (Melia 2005: p. 69), (Mulligan et al. 1984: p. 315), (Mumford 2005: p. 266ff; 2007: p. 48ff), (Parsons 2005: pp. 167-168; 2006: p. 601), (Simons 2005: pp. 255-256), and (Smith 1999: p. 285). I reject T- M in this paper. In this spirit, Asay "adamantly reject[s]" the idea that T- M is a "sine qua non of [TT]" (2011:p. 11).

${ }^{4}$ Opposition to rejecting T- M is fierce. For it is an important part of what Cameron calls "[o]rthodox truthmaker theory" (2008c:p. 107). Molnar goes so far as to call its rejection "the way of ontological frivolousness [and] a truly desperate resort" (2000: p. 85). It is interesting to note, however, that Armstrong, probably its main champion (2004: p. 5; among others), formerly seems to have subscribed to a non-T- M view of TT. His first discussions only considered truthmakers for contingent truths (1969: p. 23; 1989: p. 88). TT-skeptics such as Dodd (2007: pp. 393-394) and Merricks (2007: pp. 40-41) think that TT-ists should be $\mathrm{T}$ - M-ists on the grounds that any truthmaker-principle must concern truth in general, not just some truths. Dodd describes remaining a TT-ist while rejecting T- M as "a failure of nerve" (ibid.: p. 394). He argues on this basis that TT must be weakened (2002: pp. 74-75) and inevitably rejected (2007: pp. 383-396). See also Merricks (ibid.: §3), though he argues that a weakened truth-supervenes-on-being (TSB) view, specifically a "worldwide local TSB" (ibid.: §4.3, p. 85), can account for negative existentials. Oliver (1996) thinks that these issues should be approached optimistically. He writes, " all of this is work to be done, so the theory of truthmakers is an avenue for future research" (ibid.:p. 74). Dodd, however, points out that all this future research and fiddling with the details of TT (e.g. rejecting or not rejecting T- M) "is pointless" (2002:p. 70 , fn. 2). My stance is that providing a metaphysically substantial account of TT is pointless, but TT itself is not pointless, because a more modest view, which rejects T- M non-arbitrarily, is at least plausible.

5 Of course, there are plenty of other, non-analytic philosophers who have accepted negative beings, including, famously, Meinong (1904/1960:p. 83; see [Berto 2013:p. 70, and §§5-6] for the varieties of Meinongianism), and phenomenologists, such as Sartre (1956: p. 42). Sartre seems to provide a kind of realist truthmaker-account of non-being, when he writes, "non-being does not come to things by a negative judgment; it is the negative judgment, on the contrary, which is conditioned and supported by non-being" (ibid.). However, McCulloch (1994: pp. 7-8, 35-36) argues that, as a phenomenologist, Sartre understands 'real' as " phenomenologically real" (ibid.: p. 7) or "experientially real" (ibid.: p. 8), where real non-beings are understood in terms of what Sartre calls "living possibilities" (Sartre 1956: p. 80) or, on McCulloch's interpretation, "epistemic possibilities" (ibid.: p. 36) in the "conscious mental life" (ibid.) of an agent (cf. Hammond et al. 1991:p. 115). If McCulloch is right, the phenomenologist's account of non-being is not
} 
who are willing to accept negative facts, or negative beings of any sort, into their ontology. ${ }^{6}$ Accepting negative beings into one's ontology is biting the Russellian bullet.

To understand Russell's strategy, we need to understand the subtle distinction between Meinongianism and Russellian negative facts. Russell tries to avoid what is taken to be an unsavoury Meinongian ontology, in which there are things that do not exist. ${ }^{7}$ By contrast, his view does not commit us to the existence of things that do not exist (e.g. Pegasus), but rather commits us to the existence of the fact that some thing does not exist or the fact that something is not the case. ${ }^{8}$ Thus, instead of existing negative things, we have existing negative facts. However, this still makes negativity part of reality, and thus the taste of unsavouriness remains.

Plenty of others have also tried to find truthmakers for negative truths. For example, Martin posits "absences" (1996: p. 57), ${ }^{9}$ which according to him are "non-abstract, [...] localized states of the world or universe, and therefore, though not things or

\section{Footnote 5 contiuned}

the troubling sort we're concerned with. For, as I would put it, Sartre is talking about something else when discussing negative truthbearers than we are; he's talking about aspects of the conscious lives of agents. This further highlights the importance of the right account of what truthbearers are about for an account of their truth and truthmakers.

6 Barker and Jago (2012: p. 121) claim that "negative facts exist in just the same sense of 'existence' as positive facts (and every other kind of being). Negative facts are non-mereological wholes just as positive facts are and so have the same kind of existence. What differs between negative and positive facts is the kind of non-mereological composition involved" (ibid.: p. 121). They continue, arguing that negative facts conform to an acceptable Eleatic principle concerning their causative role, "including their roles in causation, chance-making and truth-making, and in constituting holes and edges" (ibid.: p. 117). There is no space to go into their new theory of negative facts in depth. Jago (2011) presents some formal results about their theory. Jago $(2012 ; 2013$ : especially $\$ \S 4-7)$ uses their theory to argue that positing negative facts is the best option for T- M-ists, preferable to Armstrong's and Martin's accounts.

7 Cf. Read (2012), who thinks that the right response to P- NEG is to adopt another version of the truthmakerprinciple, which utilises the terminology of Meinong's Principle of Independence, on which truth supervenes on so-being rather than on being or on entities. Thus, he advocates the principle which he calls "Supervenience of Truth on So-Being (ST): Truth supervenes on how things are: there can be no difference in truth without a difference in how things are" (ibid.: p. 251; my emphasis). Thus, as he understands it, truth depends not on what exists, but, rather, on how things are. This is indeed an attractive view and is not the aspect of Meinongianism that is normally taken to be unsavoury. Following Lewis (1999) and Dodd (2002), I take versions of TT in terms of how things are, rather than just whether things are, to be more modestly attractive than ones solely in terms of the latter. See also Yablo's (2014: \$5.7) treatment of negative existentials. He claims not to be a Meinongian, but he clearly doesn't think that Meinongianism is as unsavoury as it is normally made out to be. He writes, "Meinong was wrong, let's agree. But the idea of nonexistent objects nevertheless available to serve as referents is not absurd in itself. Pegasus doesn't exist fails to be true only because this coherent idea is false" (ibid.: p. 90). Yablo's treatment is sympathetic to Meinong, albeit not fully Meinongian. However, his account of the aboutness of empty names yields results, for instance that truthbearers such as 'Pegasus doesn't exist' turn out not to be true, which I think we should avoid in our account of the aboutness and truth of such truthbearers.

8 See (Russell 1905: p. 45) for his "chief” (ibid.) objection, which accuses Meinong's view of non-existent objects, such as the round square and the present King of France, of breaking the law of contradiction. In (Russell 1961), he writes, "The desire to avoid Meinong's unduly populous realm of being led me to the theory of descriptions" (ibid.: p. 17). See (Smith 1985) for a historical and critical discussion of The Russell-Meinong Debate.

9 See also Kukso (2006). Cameron (2008c: pp. 107-108) calls such attempts to ground negative truths in absences, "metaphysical smoke and mirrors" (ibid.:p. 107). 
natural properties or relations of things, they can serve as truthmakers for negative existentials" (ibid.: pp. 57-58). Armstrong posits "totality states of affairs" (2004: p. 58; 1997: pp. 137-148) where the-world-as-a-totality is such that there is no cat on the mat. ${ }^{10}$ Cameron (2008b: p. 415ff; 2008d: p. 295) says that the essence of the world itself makes true all negative truths. The problem with these views is that each of them still posits some sort of negativity in the world in addition to the positive, though perhaps in a more palatable manner than Russell or Meinong. To accept this, one must be willing to bite the Russellian bullet and leave that "unquenchable desire" (1919:p. 287) unsatisfied. ${ }^{11}$

Instead, one might attempt to address the dilemma's first horn by restricting TT's scope to a subset of primary truths, such as positive truths. For instance, on the so-called "moderate view" (Mellor 2012: p. 96; see also [Heil 2000]):

$[\mathrm{O}]$ nly some truths, the primary truths, have truthmakers, while other truths and falsehoods are derivable from the primary truths by means of truth-conditional semantics. [Forrest and Khlentzos 2000:3]

Similarly, according to the Wittgensteinian version of logical atomism, labeled "optimalism” by Simons (2000:p. 17) and MacBride (2014: 2.2 ), "[I]t is only atomic propositions that represent the existence of states of affairs" (ibid.). On this view, negation ' $\neg$ ' is understood purely as a truth-functional connective and truthbearers with negations are understood as molecular truthbearers, mere negations of atomic truthbearers. Negative truths, understood as true truthbearers with negations, get their truth-values, as Mulligan et al. write, "simply in virtue of the fact that the corresponding positive sentences have no truth-maker" (1984:p. 315). Or, as Simons says, they get their "truth by default" (2008: p. 14; also 2005: p. 255). On this account, negative truths do not require truthmakers, for they are not atomic truths, all of which must be positive.

It is an interesting historical fact that by contrast to these philosophers who think that logical atomism (or something similar) can address P- NEG, Russell (1918: p. 211ff) claims that one must posit negative facts for negative truths on the basis of his logical atomism. His basic point is that there is no way to account for negative truths without positing negative facts, even on a logically atomistic theory where only atomic truths are made true and only atomic facts exist. If Russell is right, then any strategy such

\footnotetext{
10 Armstrong accepts that his totality state of affairs or "the all state of affairs" (2004:p. 58) is what he calls "a 'no more' state of affairs" (ibid.) and hence partially negative (ibid.). However, he thinks that his account is far more economical than Russell's, since it posits only one negative state of affairs (the one that closes the aggregates) while Russell posits one for every negative truth.

11 For why negative facts are so repugnant, see especially Molnar (2000: pp. 76-77, and 84-85), who argues that everything that there is must exist positively. And since negative facts are not positive, they are debarred from the realm of being. Against this kind of view, some have argued for the causal efficacy of negative entities. In arguing for the causal nature of perception, Goldman (1977: pp. 281-282), for instance, argues that we perceive black holes in virtue of the fact that we perceive the absence of light, which is caused by them. Sorensen also extensively defends the view that we are constantly causally interacting with absences (such as shadows and such things as black letters), which he calls "dark things" (2008:p. 29, passim), by directly perceiving them (also in an attempt to vindicate the causal theory of perception). Schaffer (2004: passim) has plenty more examples.
} 
as the moderate/optimalist view cannot merely assume that negative truths can be accounted for by primary or atomic truths. Let me explain his reasoning.

Purely as an example, take Mellor's (2012: p. 105) ingenious strategy for accounting for negative truths. Let's take it (following Mellor's notation) that $\langle P\rangle$ is a primary truthbearer and $S$ is its truthmaker. Mellor (ibid.) explicitly states that ' $<$ not- $P>$ [which he takes to be a non-primary truthbearer] is true if and only if $S$ does not exist' is acceptable on the moderate view because $<P>$ and $<$ not- $P>$ must satisfy the laws of non-contradiction and excluded middle. Negative truths, according to Mellor, are truth-functions of primary propositions, and can satisfactorily be accounted for by the existence of truthmakers for the primary truths and the laws of logic applied to them to form non-primary propositions.

Russell would argue that this won't work and is the wrong way to understand negation and falsehood. Mellor's strategy is similar to Demos's (1917), to which Russell is responding (1918: p. 211-214). The question Russell presses on Demos is: how should we interpret 'not- $p$ '? Russell summarises Demos's proposal thus, "when we assert 'not- $p$ ' we are really asserting that there is some proposition $q$ which is true and is incompatible with $p[\ldots]$ That is [Demos's] suggested definition:

'not- $p$ ' means 'There is a proposition $q$ which is true and is incompatible with p'.” [Russell 1918:213] ${ }^{12}$

Mellor's appeal to the laws of non-contradiction and excluded middle to explain the non-primary status of negative truths is similar to Demos's proposal; it seems merely to re-describe the incompatibility which is central to Demos's strategy as a law of logic. Russell responds to Demos in several ways, but the main line of response is to explain that this strategy, as he writes, "makes incompatibility fundamental and an objective fact, which is not so very much simpler than allowing negative facts" (ibid.). According to Russell, if one tries to interpret or define negation, 'not', in this way, then one is reducing it to incompatibility. Unless there is a corresponding primary incompatibility-fact to which 'that $p$ is incompatible with $q$ ' corresponds, then we are left with an unexplained molecular fact, since the fact that $p$ cannot account for the molecular fact that $p$ is incompatible with $q$ and 'incompatible' just means 'not compatible'. ${ }^{13}$ Similarly, appeal to the laws of non-contradiction and excluded middle, as Mellor does, cannot do the job, as the truth of logical laws requires as much explaining as the truth of anything else. And further, I would add, these laws mention negation, so negation cannot be explained in terms of them.

Russell's problem, for atomist strategies and for strategies similar to Demos's, is one that everyone in the literature who aims to take the first strategy, of denying T- M, must address. Specifically, they must explain how to account for negation, and for the truth of negative truths, in such a way as to avoid commitment to negative facts or incompatibility facts.

\footnotetext{
12 Demos says, "The word "not" is precisely a symbol for this qualifying predicate [i.e. "opposite," or "contrary," or "inconsistent with" (ibid.)], and "not- p" means "opposite, or contrary, of p"” (1917: p. 191). 13 As I shall make clearer in Sect. 4.2.2, we might say that that $p$ is incompatible with $q$ is what Quine (1960: pp. 137-138) calls collateral information, information that is not part of the content of 'that p'.
} 
Thus, we need to find a strategy to accept TT, whether in the Maximalist form, which would posit some sort of non-repugnant truthmakers, or in the restricted, moderate nonMaximalist form, which would explain why some truthbearers do not need truthmakers for their truth. ${ }^{14}$

\section{Addressing Molnar (2000)}

Molnar (2000: pp. 84-85) presents P- NEG with four claims, each independently compelling for TT-ists:

(M1) The world is everything that exists.

(M2) Everything that exists is positive.

(M3) Some negative claims about the world are true.

(M4) Every true claim about the world is made true by something that exists.

The problem is: (a) given M1-M4, TT-ists are compelled to provide positive truthmakers for negative truths, but (b) non-repugnant, positive truthmakers are not forthcoming.

Broadly, the two main problem-solving strategies are: (1) reject one of M1-M4, or (2) somehow reject Molnar's picture of the problem altogether.

The proposal of this paper is that the strict-and-full aboutness account of TT (SAC), presented in Sect. 4.2, has the resources to allow us successfully to take strategy (1) by rejecting M4 in a non-arbitrary, intuitive way (Sect. 5).

\subsection{Cameron and Parsons's strategy for addressing Molnar}

Before I move on, I want to discuss a strategy that rejects Molnar's picture of the problem altogether. Cameron (2008b) and Parsons (2006) claim not to understand what the distinction between negative and positive things is; 'negative' and 'positive' each applies, at best, only to representations and not to things. Cameron writes,

[W] hat is 'negative ontology'? What is it for a thing to be positive or negative? I have no idea. [...] I don't believe this is my fault. Being positive or negative seems to apply, in the first case, to representational entities such as propositions. [...]

\footnotetext{
14 Dodd calls these two strategies "the horns of a nasty dilemma" (2007: p. 386). One might think, however, that these strategies are not exhaustive, but serve as a good guide to the two best (but still nasty) potential strategies for the TT-ist. Mumford (2007) tries to take a third way and aims to retain T- M but to "eliminate" (ibid.: p. 51ff) negative truths, on the following basis. The best philosophical account of them is to treat them all as falsehoods, and then to give a theory of falsehoods as not requiring any metaphysical commitments. His answer, as he admits (ibid.:p. 67), disrespects the "everyday conception of truth" (ibid.) while respecting "the metaphysical commitments of truth, as [TT] represents them" (ibid.). The account that I present here aims to respect the everyday conception of truth and the right view of TT that it entails. The main difference between the two strategies is that while Mumford eliminates negative truths and reduces them to falsehoods, I aim to respect negative truths by maintaining the distinction between them and equivalent falsehoods, within the framework of a more modest version of TT. In Sect. 6.2.4, I argue that the view I present is more conservative than his.
} 
Most things are not representations, so it seems that we can call them 'positive' or 'negative' in a derivative sense at best. [2008b:412-413 ${ }^{15}$ ]

Parsons (2006: pp. 591-592) claims not to understand what it is for things to be positive:

Just what is it for a chair, a person, or a rock to be positive? I have honestly no idea. Whatever sense of 'positive' is meant here, it must be different from the unclear, but not totally opaque, sense in which the proposition 'there are chairs' is a 'positive proposition'. The latter has something to do with the representational properties of the proposition in question; but a chair does not represent anything, so it is not positive in that sense. [ibid.]

I sympathise with their strategy. Let's assume that the distinction is indeed much clearer as applying to representations, and that negativity and negation are features of representations, not of things.

\subsection{The real distinction between negatives and positives}

However, even if the distinction does not apply to things, there is an important sense that is compatible with this, in which there is a real distinction between negative and positive, ${ }^{16}$ where the distinction applies not just to representations but to reality. For example, there is a real distinction between the sweater I am wearing being yellow and the sweater I am wearing not being yellow. ${ }^{17}$ There is a real difference between

\footnotetext{
15 Cameron (ibid.: p. 413) critically discusses Molnar's M2. However, he is best understood as rejecting not just M2, but the assumptions about negative ontology which lie behind Molnar's whole way of setting up the problem. His positive solution is that the world has all its properties essentially. The world, according to him (ibid.: p. 415ff), makes true all negative truths. He doesn't, however, explain how this solution addresses Molnar's set-up except to argue that Molnar doesn't provide "any particular reason for thinking that negative truths resist truthmaking" (ibid.). This is because he rejects the idea of a real distinction between negative and positive. According to him, "The only problem worth taking seriously $[\ldots]$ is the intuitive dissatisfaction with the extant accounts of such truthmakers [for negative truths]" (ibid.). I try to answer the problem, as construed by both Cameron and Molnar, though I don't have space to address Cameron's positive account directly.

16 By saying that there is a real distinction and using the word 'distinction', I do not mean to commit myself to the existence of a further entity a distinction. Rather, I am merely claiming, and in this section arguing, that there is a difference of some kind and that the difference is a real-world difference rather than merely a difference in the way we represent the world. Which kind of (real-world) difference we are concerned with depends on that which we are distinguishing rather than the difference itself. Although it is an interesting question to answer, I think that one can be neutral about the ontology of distinctions and differences when one is affirming that there is a real distinction or difference. For it is not directly relevant nor necessary for affirming a real distinction between $\mathrm{X}$ and $\mathrm{Y}$ that one also claim that distinctions are entities, properties, relations, or whatever else. Perhaps we can be pluralists about the nature of distinctions and differences. In our case, we are making a distinction between nothing and something. What the exact nature of this distinction is in regard to its ontological category is an interesting and indeed important further question that one can try to answer after one has affirmed that there is such a distinction. My aim here is merely to argue that the distinction is real rather than representational, and that is sufficiently informative about the nature of the distinction in question for the purposes of this paper.

17 Just to be clear about this, the distinction is not just a matter of two distinct states of affairs at different times, specifically the sweater I am wearing being different at two different times. Rather, the distinction concerns two possible ways the sweater I am wearing is: (1) its being yellow; and (2) its not being yellow.
} 
the sweater being some way and its not being that way, even if this is not a difference between features of things, features which the things have. The sweater not being some way is not a feature of the sweater. The distinction is not, and was never supposed to be, between positive features of things nor between positively existing facts in the world. For the sweater not being some way is not a positively existing fact. Rather, the distinction is between things being some way and things not being some way. When I say that the sweater I am wearing is not yellow, if what I say is to be true, then the sweater must not be yellow. There is a clear distinction between the sweater's being yellow (in which case what I say would be false) and the sweater's not being yellow, which is no fact at all. ${ }^{18}$ This distinction is not merely representational but real. In the former case, the sweater really is that way, and, in the latter case, the sweater really is not that way. 19

In response to the claim that the sweater's not being yellow is not a fact at all, one might say, "But, as a matter of fact, my sweater is not yellow, but green." One might naturally think, on this basis, that the sweater's not being yellow is a fact, a negative fact that contrasts with another fact, the positive fact that my sweater is green.

In a loose way of speaking about facts, as true truthbearers, this is correct. No one, including Cameron and Parsons, denies that there is a distinction between negative and positive truthbearers, marked at the very least by the presence or absence of a negation. Negative facts of the true-truthbearer sort are not at issue. The problematic, unsavoury sort are negative facts understood as Russellian complex, structured entities. But, Russellian facts are complex, structured entities that are constructed out of properties and the objects in which the properties in question are instantiated. The reason why the sweater's not being yellow is no fact at all (as I say above) is that not being yellow is not a property. Rather, it is a lack of a property; it is nothing at all. Not even Russellian facts can be constructed out of nothing. So, the sweater's not being yellow is not a Russellian fact, that is, a structured, complex entity over and above the sweater and how things are with the sweater. Yet, as I have argued, the distinction between the sweater's being yellow and the sweater's not being yellow is a real distinction marking real differences not to do merely with representations (or truthbearers) but with reality.

\footnotetext{
18 In the next paragraphs, I explain why the sweater's not being yellow is no fact at all.

${ }^{19}$ I am using 'really' here not in the sense that has become popular from the work of Fine (2001:p. 25ff) and Cameron (2008a: p. 6f; 2010a:p. 251; 2010b: p. 8ff) where there is a distinction between really existing and merely existing, marking out two types or ways of existing. See Hale and Wright (2009: p. 186) for a criticism of the distinction. Instead, I use 'really' or 'real' in the non-technical, everyday sense where it is contrasted with such adjectives as 'illusory' (see [van der Schaar 2011: p. 409]). There are not two types of object or ways things can be, the real and the not-real; only when objects are real are they objects, and only when the ways that they are are real are they those ways. As Austin (1946: p. 87) explains, 'real' is not a determiner and only makes sense in the context in which doubts have been raised or some hypothetical (or even fictional) context is explored. See (van der Schaar 2011:p. 410) for a helpful exposition of this sense of 'real' in the context of distinguishing between illusory and real cognitive acts. Also, she (2011:pp. 398-399) helpfully explains that adjectives such as 'illusory' and others such as 'fake', 'mock', or 'sham' are modifying adjectives. Unlike attributive adjectives such as 'German', in which case one can infer 'Jack has a pistol' from 'Jack has a German pistol', one cannot infer 'Jack has a pistol' from 'Jack has a sham pistol'.
} 


\section{The aboutness-based version of truthmaker theory}

I shall now articulate the aboutness-based version of truthmaker theory (TAAT). The first, main condition of TAAT is what I shall call the aboutness condition of truthmaking (AC):

(AC): truths are made true by the parts (or aspects) of reality which they are about.

According to TAAT, truths are truthbearers that are true and made true by what they are about. Truthbearers are those entities which can be true (or false, i.e. are truth-apt) and which can be about entities and how things are with those entities (i.e. some aspects or modes of that entity's being). Truthmakers are those entities and the ways things are with those entities which truths are about. Truths and their truthmakers stand in a relation of truthmaking (T- REL) to each other.

Fraassen (1969) first articulated a version of TAAT, but, since then and until relatively recently, it has been, for the most part, neglected. ${ }^{20} \mathrm{He}$ argued that truthmaking and what he calls "signification" (ibid.: p. 481) (1) $^{21}$ "dual" (ibid.) relations. ${ }^{22}$ This is a very powerful insight. The version of TAAT I shall present understands truthmaking and aboutness as dual, or as I like to call them, complementing, relations, whose satisfaction-conditions go hand-in-hand. Thus, an insight into the best truth-relevant account of aboutness will give us an insight into the best version of TAAT.

To this end, I shall introduce and then employ what I take to be the best semantic account of what truthbearers are about (Sect. 4.1), the essentials of which are captured by what I call the strict and full account of aboutness (SAC) (Sect. 4.2). I then use the details of the theory of intentionality as fleshed out by Crane's solution to the problem of intentionality, to develop a framework wherein $p$ can be about $S$ even if $S$ does not exist (Sect. 4.3). To do this, I shall introduce the notion of aboutness-satisfaction (and -failure) (Sect. 4.4). Since aboutness and truthmaking are dual relations, when there is satisfaction of aboutness at the level of truthbearers, there will be a complementing satisfaction of truthmaking. These details will help to articulate an account of truth (and falsity) in terms of the satisfaction (or failure) of aboutness (and hence truthmaking), and, in turn, to articulate a solution to the problem of negative truths (in Sect. 5).

\footnotetext{
${ }^{20}$ Even though there have not been many TT-ists who have been explicit adherents to TAAT and AC, the account now has a good pedigree. Lewis for instance writes, "roughly speaking, truths must have things as their subject matter" (1999: p. 206; my emphasis on 'subject matter'). He also writes, "Any proposition has a subject matter, on which its truth value supervenes" (2003: p. 25). Smith (1999) uses what he calls the "total projection" (ibid.: p. 282ff) of $p$ to articulate a recent version of TAAT. He points out that "A truthmaker for a given judgement must be [that] which the judgement is about, must satisfy some relevance constraint" (1999: p. 279). TAAT and the addition of "some relevance constraint" (or what I call AC) are motivated by their ability to address two decisive problems that plague rival necessitation-based accounts of TT, namely the problem of trivial truthmakers (Restall 1996: p. 333; Lewis 2001: p. 604) and the problem of malignant necessitators (Smith 1999: p. 278). These problems are each used to argue that necessitation is not sufficient for TT. See (Merricks 2007: §2.2-2.3) for in-depth discussion.

${ }^{21}$ He clearly thinks that signification and aboutness are at least similar notions when he approvingly cites Dunn's (1996) use of the term 'about' (ibid.: p. 485).

${ }^{22}$ See (van Fraassen ibid.: p. 481) for the details of why accepting only one or the other is arbitrary. Accepting both leads to a "generous [...], not parsimonious" (ibid.) theory of TT, which I accept as a virtuous sort of modest pluralism.
} 


\subsection{What the best semantic account says truthbearers are about}

The notion of aboutness involved in TAAT is what I shall call the best semantic account of what truths are about (SEM-TAC). It is more sophisticated than any mere folk ${ }^{23}$ notion of aboutness on which, for instance, 'The average, middle-income family is economically less well off in 2016 than in 2008' might be taken to be about an entity the average, middle income family. Nor is it some metaphorical sense of aboutness, on which one might say that 'Ghosts live among us' is metaphorically about human suffering or mourning. Or, as Max Black reports, when one says, "Nixon is an image surrounding a vacuum" (1993:p. 39), presumably one is not literally talking about Nixon and stating that he is an image surrounding a vacuum, and hence not literally talking about these things. What one might be metaphorically talking about, if there even is a coherent notion of metaphorical aboutness, is anyone's guess. ${ }^{24}$

Figuring out what the best SEM- TAC says truths are about is difficult. Consider 'Brakeless trains are dangerous'. ${ }^{25}$ At first reading, and presumably this would be the apparent and folk understanding of what this truthbearer is about, one might think that we are referring to all the brakeless trains there are, and saying of them that they are dangerous. However, let's say that there are no actual instantiations of any of these things: there are no brakeless trains. On the standard analysis, these truthbearers would not be true (and would be either false on a Russellian analysis or neither true nor false on a Strawsonian understanding). The problem with understanding these truthbearers in a folk or unreflective way (and then supplementing it with the standard story of reference failure) is that we get the wrong result. Brakeless trains would be and are indeed dangerous. In fact, it is likely that the reason why there are no brakeless trains is that brakeless trains are dangerous. This truthbearer is true even though the things it is apparently about do not exist. A better semantic analysis would make the truthbearer out not to be about any brakeless trains, which do not exist, but about brakeless trains in general (or if they were to exist). Perhaps this is a law of some sort; a law concerning brakeless trains. Laws hold and statements of laws are true even if nothing is subject to them at some given time. ${ }^{26}$ Thus, it is clear that the best semantic

\footnotetext{
${ }^{23}$ By 'folk' I mean to refer to what Kant calls "the great unthinking mass" (1784: p. 55) or what Strawson calls the "unthinking multitude" (1972: p. 18' 37"). Of course, it would be the hope of every good democrat that the multitude would become a thinking multitude, and part of the role of the philosopher is to pave the way by clearing up the issues relevant to this thinking, including issues to do with aboutness.

${ }^{24}$ I cite Black here, partly because he thinks that what he calls "strong metaphors [...] can, and sometimes do, generate insights about "how things are" in reality" (ibid.). But it is clear that the aboutness involved in such strong metaphors is a metaphorical aboutness much less straightforward than the aboutness that we are concerned with here. He cites Austin (1962: pp. 98-99) as one who rejects the question "Can metaphorical statements be true?" (Black ibid.: p. 38). According to Austin (ibid.), not every statement aims at truth. For instance, the metaphorical use of a statement is a use where truth and falsity are irrelevant, and hence, may not generate any insights about how things are in reality. Whether Black or Austin is right in what they say about metaphor and truth, whatever link to the world metaphors have, the metaphorical aboutness link, if there is one, is a much less straightforward one than the literal aboutness of non-metaphorical truthbearers. 25 This example is due to Johnson (1924: part III, p. 12). It is discussed by Armstrong (1983: pp. 21-22). Yablo (2012: p. 1025) attributes the example to Lewis.

26 One might be puzzled by this suggestion, and wonder, "How can there be laws concerning brakeless trains if there are no brakeless trains? Wouldn't that mean that there are laws about nothing?" My response
} 
analysis of truthbearers is not as straightforward as the folk or the unreflective analyser might take them to be. ${ }^{27}$

\subsection{Strict and full aboutness as what the best semantic account says truthbearers are about}

What I take to be the best SEM-TAC is what I call strict-and-full-aboutness and it forms what I call the strict-and- full-aboutness-based account of TT (SAC; I shall use this abbreviation both for the notion of aboutness and for the TT-account based on it). I only have space to go into the essentials of SAC in this paper. I shall first say some general things about SAC (Sect. 4.2.1) before introducing it properly (Sect. 4.2.2).

\subsubsection{Aboutness apparatuses, pluralism, and context-sensitivity}

SAC, as the best SEM-TAC, requires that aboutness is not just a matter of reference, narrowly construed as the relation that relates singular and plural terms to their realworld-correspondents. It is a matter of the aboutness of all the parts of the truthbearer that one can use to be about entities and how things are with those entities. This is an important part of the doctrine of intentionality, which I shall be using to explicate SAC. In my understanding of the doctrine of intentionality, I follow, but also expand on, the construal given by McCulloch (1994: p. 26-31) and Crane (2013), when he says:

I am using the idea of what is 'talked about' and 'thought about' in a very general way, to apply to any thing that is what we might call the subject-matter of thought or discourse. Recall that I do not understand such 'aboutness' as reference. Reference - the relation in which singular terms stand to objects, or plural terms stand to pluralities of objects - is one way in which words can be about things, but it is only one way. Predication, too, is a way in which words can be about things. When I say that some pigs swim what I am saying is about swimming just as much as it is about pigs. 'All men are mortal' is about mortality as much as it is about all men. But it is perfectly natural to think of the sentence as being about all men too. [Crane 2013: 39]

\section{Footnote 26 contiuned}

is: Indeed. There are also plenty of other similar examples of laws about things that do not exist currently. For instance, in many places there are laws concerning the correct procedures for parking a lorry between five and seven in the morning, even though there are no lorries which are currently parking in the place in question since it is another time of day. A less conventional example might be: there are laws concerning the interaction between certain molecules even if there are no such molecules at present.

27 There are also other notions of aboutness which I don't have space to distinguish SEM- TAC from in depth here, such as the linguistic notions related to grammatical subjects (e.g. topic and focus). See, for example, Merricks (2007: pp. 32-33) who distinguishes between the sense of aboutness relevant for TT and the topic sense of aboutness. I sketch out the most important relevant features of SEM- TAC throughout my discussion. For further background on SEM- TAC, see, for instance, Yablo (2014) and Fine (2015a, 2015b) both of whom give accounts of aboutness in terms of truthmakers. Even though these accounts differ in their details, the basic aims, to give the right account of aboutness, are the same. I assume no familiarity with their treatment of either truthmakers or aboutness in my discussion. 
The way that Crane uses 'aboutness' here captures an important aspect of SAC. ${ }^{28}$ Predicates as well as singular and plural terms are part of what I shall call our toolbox of "aboutness apparatuses". These apparatuses help to determine the content of truthbearers (e.g. sentences, beliefs, judgments), especially those aspects that specify what in the world the truthbearers are about, including both which objects (via referring expressions) and how things are with those objects (mainly via predicates). McCulloch (1994:pp. 26-31) sums up this part of the doctrine when he writes, "intentional objects [that is, the objects of aboutness ${ }^{29}$ ] have turned out to be properties such as being pretty and individuals such as London, sometimes considered as combined in this or that way. The doctrine of intentionality, on this construal, is the claim that mental acts make reference to such properties and individuals" (ibid.: p. 28). ${ }^{30}$ He goes so far as to say that this so-called doctrine of intentionality "is one of the glories of analytical philosophy" (ibid.: p. 30).

An important part of SAC, and this will be central to our solution, is that language can represent in intricate ways and that the toolbox of language is very rich. The richness of the toolbox, in turn, allows us to retain a modest commitment to metaphysical tolerance, neutrality, and categorial pluralism concerning the nature of truthbearers and the nature of truthmakers. Ceusters and Smith (2015: p. 2) and Ceusters' (2012: p. 70) account of aboutness, for instance, is congruous with mine on this matter. They claim that what they call Information Content Entities (ICEs; entities with content and aboutness) "stand in [the] relation of aboutness to some portion of reality rather than just to some entity" (Ceusters and Smith 2015: p. 2). According to them, the domain of the aboutness relation includes properties, universals, relations, other ICEs, objects, their configurations, etc. For example, we can talk not just about Germany and Angela Merkel but also her role as Chancellor of Germany. This notion, that what ICEs are about are "portions of reality", underlines my point that on a modest account of TT, truthbearers should not just be about entities but how things are with entities and what I shall call a "variety of modes of being". ${ }^{31}$ Clearly on the most prominent accounts that I have discussed so far, including Crane's, and Ceusters and Smith's, aboutness is understood in an inclusive, categorially pluralist way.

\footnotetext{
28 However, I think our accounts differ in other ways which I have no space to discuss. On the point raised, Ramsey (1927: pp. 44-45) seems to agree that truthbearers can be about multiple things, perhaps also including properties, when he writes, "a proposition about 'the fact that $a R b$ ' must be analysed into (1) the proposition $a R b$, (2) some further proposition about $a, R, b$, and other things [...] We are driven, therefore, to Mr Russell's conclusion that a judgment has not one object but many, to which the mental factor is multiply related" (ibid.).

${ }^{29}$ Intentional objects will play a central role in our solution to P- NEG later.

${ }^{30}$ For more on the step from predicates to properties, though the discussion is not put explicitly in terms of intentionality, see (Martin 1997: pp. 193-194; and 1980: p. 9).

31 This is also why I say that truths are made true not just by the existence of entities but by how things are with entities (or their being, for short). Thus, truthbearers are made true not just by what exists but what exists being some way or other. Properties are ways that entities are and can be. I generally speak of properties not as existents but as ways of being. This distinction between existence and being further underpins a distinction between what exists and what is real. All that exists is real, but not all that is real exists. For example, how things are with what exists is real but does not exist. The triangularity of the table on which I am writing is real but since it is a property, a way things are with the table, the triangularity does not exist.
} 
The best SEM- TAC must reflect the various, intricate uses of languages. ${ }^{32}$ And, the best account of TT must respect and accommodate this. It must also incorporate a sensitivity to how context affects aboutness. For example, surface grammar and the normal use of words might mislead us in cases where understanding the context of use is essential to understanding what is talked about. Consider another example, discussed by Bigelow (1996: p. 39):

If you say that Othello loves Desdemona, in a sense which does not require the existence of Othello, then what is said is really not something about Othello at all, but about something else, perhaps we are just saying something about Shakespeare's play (whatever that is) or about Shakespeare and what he said. [ibid.]

In this case, we are using names in apparently standard ways to talk in an existence-entailing way ${ }^{33}$ about things (here, Othello and Desdemona), but in fact the truthbearers are used to talk about completely different things (here, Shakespeare's play). In this case, plausibly, we are using these names in a different context, to talk indirectly about works of fiction rather than about people. Knowing the context in which the truthbearer is used is sometimes essential for knowing what it is about. The best SEM- TAC must also be sensitive to how context affects aboutness.

\subsubsection{SAC and derivative aboutness}

Now, I want to make a distinction between what the truthbearer in question is strictly and fully about, and what the truthbearer is derivatively about, given the truth of further truthbearers about the world not mentioned in the truthbearer in question. Consider:

T3: This table exists.

$\mathrm{T} 3$ is strictly about a particular table, while it might derivatively be about what it consists in fundamentally (e.g. the subatomic particles out of which it is constituted, or if trope-fundamentalism about tables is correct, the tropes out of which it is bundled). However, there is nothing in $\mathrm{T} 3$ that tells us anything about what the table consists in fundamentally or non-fundamentally, ${ }^{34}$ nor does it tell us anything about any tropes. These are instances of what Quine calls collateral information (1960: §2, especially pp. 137-138), that is, information that is perhaps important as background information which helps us to understand the truthbearer in question, but that is not the information conveyed in the truthbearer itself. ${ }^{35}$ The information about tropes and about funda-

\footnotetext{
32 Echoing Wittgenstein (1953: especially $\$ \$ 11-17$ and 23), language is not just richly varied in terms of the tools there are to do other things than refer, describe, or talk about the world, but it is richly varied in terms of the tools it has to talk about the world.

33 This foreshadows my discussion of existence-entailing predicates in Sect. 6.2.5

34 Let us say that some philosophers are right and the particles that the table consists of are not fundamental. Whatever we say about a table does not necessarily tell us anything either about what it fundamentally consists of nor about the various non-fundamental particles or parts that it consists of.

35 The truthbearers Quine discusses are sentences, but what he says about sentences, I think, transfers over to all truthbearers.
} 
mentality only comes with further information not contained in the truthbearer in question.

To generalise, we might say, then, that what a truthbearer is strictly and fully about is captured by the information that the truthbearer conveys irrespective of its collateral information. And to avoid such a fundamentalist and metaphysically loaded and hence semantically implausible account of what truths in general are about, we might reformulate the aboutness condition (AC) relevant for TT as one that the fundamentalist clearly rejects, what I shall call the strict and full aboutness condition of truthmaking (SAC): ${ }^{36}$

(SAC): truths are made true by the parts of reality which they are strictly and fully about. $^{37}$

SAC is the version AC of TAAT which, I think, minimally captures what we need for a plausible, modest, and useful account of TT. I shall now briefly make clear what strictness and fullness each amounts to.

\subsubsection{Strictness}

Strictness restricts what the truthbearer is about to just those entities and how things are with those entities that are specified by the truthbearer's various aboutness apparatuses, which in turn help make the truthbearer about them. It excludes any further entities to which they might be related, and excludes any other properties or relations that the entities described might instantiate other than the ones mentioned. For example, the truthbearer 'the table is black' is strictly about the table and that it is black, and not strictly about any of the table's constituent parts or its shape. As I made clear in the previous sections, specifying exactly what the truthbearers are strictly about is not always straightforward. But, I think that it is safe to say that what the best SEM- TAC says any given truthbearer is strictly about corresponds to important features of the context in which the truthbearer is used to be strictly about certain parts of the world, rather than others. For instance, a competent user of aboutness apparatuses in English may use an English-language truthbearer such as 'the bank is empty' to be strictly about the lack of people in the bank in whose lobby he is standing, while another competent user might use the same truthbearer to be about the lack of gold bars in the safe of the bank which he is robbing. ${ }^{38}$ Neither the normal client who is visiting the bank during his lunch break, nor the unlucky bank robber, are talking about fundamental particles

\footnotetext{
${ }^{36}$ Adding to what I said in Sect. 4.2, 'SAC' will be used to refer to the condition as well as to the notion and account.

37 One might add 'minimally' or 'at least' after 'made true', because one should not completely rule out the fact that truths can be made true (non-minimally) by the portions of reality of which the minimal truthmakers, which the truths are strictly about, are part. But any non-minimal truthmakers are only truthmakers derivatively or indirectly because they have the minimal truthmakers as parts. Also, as I mentioned earlier, Smith (1999) defends a similar aboutness-based view of truthmaking which involves what he calls a "relevance constraint" (ibid.: p. 279). Smith's account, however, is different from the one presented here in ways that would take us too far off track to discuss. See Gregory (2001) for a critical discussion of Smith's account.

38 See also Brogaard and Smith (2000: p. 53), whose treatment of 'this glass is empty' in their discussion of context switches is comparable to my treatment of 'the bank is empty'.
} 
of any sort. Also, in some cases and in some contexts, the surface structure of the truthbearer might not transparently reveal what the truthbearer is strictly about. For instance, when Jack tells Sally that he has left his children in the lurch by opting to go to the pub instead of helping them with their homework, he is not talking about a place the lurch, in which he has left them. As a competent speaker of English, Sally would be able to understand what Jack is strictly talking about, even though they both would most likely need to use collateral information to give a speaker of English unfamiliar with that phrase an understanding of what Jack is strictly talking about.

The strictness constraint is similar to Yablo's proportionality requirement on aboutness (2014:pp. 75-76). In explaining this requirement, he writes:

Truthmakers should on the one hand not incorporate irrelevant extras, in whose absence we'd still have a guarantee of truth. What makes it true that there are dogs? Proportionality favors the fact that Sparky is a dog over the fact that Sparky is a black-and-white cockapoo; the extra detail is unneeded. [ibid.: p. 75]

Proportionality and strictness yield the result, and capture the intuition, that not just is it unneeded, but it is not strictly relevant that Sparky is a black-and-white cockapoo. What is relevant is that there are dogs. And Sparky is a truthmaker only in virtue of his being one of the dogs that exist. See also (ibid.: p. 13-14) for a discussion of other examples relevant to this. In particular, strict aboutness as a requirement on the relation between truth and truthmakers has a parallel in Confirmation Theory (ibid.: p. 13). Consider a problem called "tacking by disjunction" (ibid.: p. 13; see also Moretti 2006). Take the truthbearer 'all ravens are black'. The truthbearer is confirmed by its true consequences. But, some true consequences better confirm it than others. For example, 'this raven is black' better confirms the truthbearer than 'this raven is black or the sky is pink or Sally loves sauerkraut'. Similarly, the truthbearer is not strictly about any of the things tacked on as a disjunct (in the latter), while it is strictly about this raven, as well as all other ravens. Though, as we'll see in my next point, it is not fully about this raven; it is fully about all ravens.

\subsubsection{Fullness (and partiality)}

Fullness indicates that what the truthbearer is about is everything that the aboutness apparatuses make the truthbearer about, including all the entities and how things are with those entities, and not just any single thing mentioned or described. For example, the truthbearer 'the table is black' is fully about both the table and that it is black and not just the table or blackness-in-general or even its blackness. It may be partially about these latter things, but not fully (or wholly) about them. The truthbearer 'all ravens are black' is strictly about each and every raven but it is also fully about all of them, and their being black.

As with strict aboutness, sometimes it is not straightforward to give an account of what exactly a truthbearer is fully about. For instance, how partial and strict aboutness and further non-aboutness apparatuses, perhaps such as truth-functional connectives, affect full aboutness, can be complicated. A fully developed theory of these matters cannot be given in this paper. However, with regard to partial aboutness, I am inclined to claim that truthbearers are partially about the various things (and how things are 
with those things) that the various aboutness apparatuses that make up the truthbearer refer to. ${ }^{39}$ For instance, that the table is black refers to a specific table. So, it is partially about that table. Yablo (2014:p. 14) talks in terms of truthbearers being wholly true, which I think is related to my notion of fully about. Take the conjunction 'the table is black and the table is round'. This truth is made true in part by the table's being black, and in part by the table's being round. As Yablo puts it "True parts confer partial truth on their wholes" (ibid.). As should be clear, the true parts confer partial truth on their wholes, because the whole truthbearer is in part about what the parts are about. But, for the whole to be true, all the truthbearer-parts that it is a conjunction of need to be true. And, for the truthbearer to be wholly true, all the various things it is wholly or fully about, via the aboutness apparatuses and truthbearer-parts out of which it is composed, need to make it true.

In the case of disjunctions, I think the right account formulated in these terms should say that the disjunction is fully about each of its disjuncts. Thus, the truthmakers for any of the disjuncts will make true the whole truthbearer, which is constructed out of the disjuncts and the disjunction connective. Although such truthbearers are strictly about many more things than each of the things it is fully about, the truthbearer can be made true by any of the disjuncts, each of which it is fully about. Fine (2015b) treats the truthmakers of disjunctions in a similar way, when he discusses what he calls "the notion of being partly about" (ibid.: p. 3; see also 1).

\subsection{SAC and the problem of intentionality}

I shall now, in Sects. 4.3 and 4.4, present the aspects of SAC which allow us to answer PNEG. According to TAAT, when some truthbearer is about some particular truthmakers, then that truthbearer is made true when those truthmakers have being. Of course, on the standard understanding of the aboutness relation (A- REL), a truthbearer can be about some truthmaker, even if the truthmaker does not have being. A- REL does not seem to require the existence of the entity which it is about. A truthbearer, or some term which helps constitute a truthbearer, can be about things which do not exist. According to Crane (2001: p. 23), this is "undeniable" (ibid.) and a "manifest fact" (ibid.). Consider:

T4: Pegasus exists.

T4 is about Pegasus. So there seems to be an A- REL between T4 and Pegasus. But Pegasus does not exist. For T4 to be true, according to TAAT, the truthmaker, namely Pegasus, would have to exist. But since Pegasus does not exist, there is no truthmaker for T4. So, T4 is false. There seems to be a disanalogy here between A- REL and TREL. However, a complication arises from this supposed disanalogy. Specifically, it is also an undeniable fact about relations that no relation can exist without its relata

\footnotetext{
39 Merely because doing otherwise can make the sentence constructions rather awkward, I sometimes speak loosely, saying that one can refer to properties, as well as to objects. (See Sect. 4.2.1 for why this would be loose-talk.) Also, I talk about the aboutness apparatuses referring. Perhaps this is shorthand for them being used to refer rather than themselves referring. I am agnostic about these issues.
} 
existing..$^{40}$ By analogy, if Jon is shorter than Wendy, then the relation shorter than exists or holds between Jon and Wendy. And for this to be the case, Jon and Wendy need to exist. Thus, T4 cannot be about Pegasus if the thing that it is about does not exist. But, Pegasus does not exist! What gives?

Broadly, this is what Crane (2001:p. 22ff) calls "the problem of intentionality" (P- INT). The problem is that there is a conflict between these three claims: ${ }^{41}$

C1: All truthbearers are related to the things they are about.

C2: Relations entail the existence of their relata.

C3: Some truthbearers are about things which do not exist.

The question is: How can $\mathrm{C} 3$ be true, given $\mathrm{C} 1$ and $\mathrm{C} 2$ ? $\mathrm{C} 3$ is clearly true given truthbearers such as T4. Since C2 and C3 are plausibly undeniable truths, the way to resolve $\mathrm{P}$ - INT is to reject $\mathrm{C}$.

To do this, I now introduce the notion of an intentional object..$^{42}$ These are just the schematic objects of attention; the things thought about. Such things are not restricted to objects in the ordinary sense (ibid.: 16) ${ }^{43}$ they are objects in the broader sense that

\footnotetext{
40 See Crane (2001: pp. 23-28), who thinks this is also undeniable. To illustrate, he discusses statements such as 'there are lots of things which do not exist: for example Pegasus' (ibid.: p. 24). One of the ways to hold such a view about, say, Pegasus is to make a distinction between what's real and what exists. Pegasus, in this case, is real, but does not exist. Relations relate real things, but not necessarily things that exist (e.g. there can be relations between properties, and properties do not exist even if they are instantiated in objects and thus have being). Thus, I would amend the claim to be that it is an undeniable fact about relations that no relation can exist without its relata being real, rather than that its relata must exist. As should be clear, even though I distinguish between what's real ( has being) and what exists, I don't use 'real' in Crane's way (see footnote 19 in Sect. 3.2 for an explication of my use of the word 'real'). Pegasus neither exists nor is real, since Pegasus is a mythical creature and mythical creatures are not real creatures. Thus, I agree instead with Russell when he says: "Logic, I should maintain, must no more admit a unicorn than zoology can; for logic is concerned with the real world just as truly as zoology, though with its more abstract and general features" (Russell 1993:p. 47; also quoted in Crane ibid.:p. 24). One might wonder, further, whether the relata must exist simultaneously when Crane says that it is undeniable that they must exist if a relation between them exists, or whether simultaneous existence is not necessary. For instance, can one still love one's dead spouse or see a distant no-longer-existing heavenly body? (I thank an anonymous reviewer for raising this question.) My response is that even though I should stay neutral about this issue for the present purposes since it would get us into some deep and difficult issues in the metaphysics of time, my intuition is that indeed present things can be related to past things. My cat is now clearly older than when I rescued it. The relation being older than clearly relates the presently existing cat with its past self. Thus, simultaneous existence (or reality) is not necessary for relations to hold between things. However, I leave this issue to be resolved at another time.

41 This is adapted from (Crane 2001:p. 23), though he focuses on thoughts rather than truthbearers-ingeneral. He considers "thoughts [as] relations between thinkers and the things they are about" (ibid.). P- INT concerns all intentional states, such as singular thoughts, hopes, desires, and beliefs. Our topic is the relations between truthbearers and truthmakers. So, I restrict the discussion to them without any substantial loss of relevant content.

42 I follow (Crane ibid.: p. 13ff). But, the history of this notion traces back at least to the medieval period. More recently, Husserl uses it throughout his writings and theory of intentionality. Although there are differences in our uses of the notion, we seem to agree when Husserl writes, "It is a serious error to draw a real distinction between [...] "intentional" objects, on the one hand, and "transcendental", "actual" objects, which may correspond to them, on the other. [...] The intentional object of a presentation is the same as its actual object, and, when appropriate, as its external object. [...] The transcendent object would not be the object of this presentation, if it was not its intentional object" (Husserl 1970: pp. 595-596); see (McIntyre and Smith 1982: p. 5).

${ }^{43}$ Searle(1983: p. 18) discusses 'ordinary objects' in this context.
} 
they can be objects, particulars, properties, events, states, processes, etc. So, unlike the ordinary, substantial sense of 'object', according to Crane (ibid.: p. 15), the schematic, intentional objects of attention clearly do not need to have anything in common with each other, except that they are objects of thought. Further, that there is no essential nature to truthmakers fits nicely with the truthmaker-pluralism of Sect. 4.2, and is something I take to be a virtue of the account.

Importantly, they are not what Searle calls "shadowy intermediaries" (1983: p. 17). They are just the entities that the truthbearers are about. They are not further "representation in our heads" or "ideas in our minds" (Crane ibid.:p. 16) which we need to be thinking about when we are thinking about other entities such as tables. There is no reason to think that one is thinking about some idea to be thinking about a table ([ibid.], though the existence of such ideas might be part of the story about how intentional states such as truthbearers can be about tables and other things [ibid.: pp. 28-33]). Sometimes our thoughts and truthbearers are about ideas and representations, sometimes they are about tables. Thus, the intentional objects are just those objects that the truthbearers are about.

Crane (ibid.: pp. 15, 17) tries to explain how intentional objects are not "shadowy intermediaries" by drawing a parallel between the schematic idea of object and the grammatical idea. ${ }^{44} \mathrm{He}$ illustrates this with the example of transitive verbs such as 'kicked', 'played', or 'called'. They take objects. (For example, 'Ernest kicked the ball', 'Emily played the piano', and 'Emily called Ernest' each have a direct object.) We understand this when we learn grammar. But, we do not need to have a substantial conception of object to understand this. Crane writes, "All we need to know is that the object is something which plays a certain role in the sentence" (ibid.: p. 15). Analogously, when our truthbearers (and thoughts, desires, etc.) are about things, those things are intentional objects which merely play a certain role in our truth-apt constructions (or thoughts) but do not have substantial natures; they are not objects in the ordinary, substantial sense. Just as we have a good grasp of objects in the grammatical sense (illustrated by our linguistic mastery and understanding of the examples above), we have a good grasp of objects in the schematic sense of (intentional) objects of concern. ${ }^{45}$

This strategy lets us accept $\mathrm{C} 3$ : some truthbearers are about things that do not exist, or in other words "there are intentional objects which do not exist" (ibid.: pp. 22 and 25). When we answer 'Pegasus' when we are asked what T4 is about, we are talking about Pegasus, the intentional object of $\mathrm{T} 4$. But we are not, in this case, referring to anything, since "Pegasus [is] nothing" (ibid.: p. 25). Now consider T5:

\section{T5: Zeus exists.}

\footnotetext{
44 Unlike Anscombe (1965: especially 161), however, he does not think that intentional objects are grammatical objects or that the idea of an intentional object is a purely grammatical one. This is just a helpful analogy.

45 See Gorman (2006: pp. 137-138) who is skeptical of the substantial-schematic distinction applying to intentional objects. However, his skepticism is rooted in the fact that Crane does not explain further "how [his] understanding [of] intentional objects [...] permits intentional states to have non-existing objects" (ibid.: p. 138). My discussion of satisfaction (below) implicitly addresses this worry. Gorman also introduces what he calls "satisfaction-conditions" (ibid.: p. 140) to address this worry, albeit slightly differently than I do.
} 
According to Crane, "neither Zeus nor Pegasus exists; both Zeus and Pegasus are nothing" (ibid.), but what distinguishes $\mathrm{T} 4$ and $\mathrm{T} 5$ from each other as intentional states (thoughts or truthbearers) is the fact that $\mathrm{T} 4$ is about the intentional object Pegasus while T5 is about the intentional object Zeus. According to Crane, this allows one to accept both $\mathrm{C} 2$ and $\mathrm{C} 3$ as undeniable, while rejecting $\mathrm{C} 1$. The way I think that we should understand Crane, then, is to see him as denying that all truthbearers are related (or "involve relations" [Crane ibid.: p. 26]) to the things they are about. Sometimes the things they are about do not exist and are not real, as with T4 and T5. In these cases, the truthbearers have intentional objects which they are about, but they are not related to any existing, real intentional objects. This is not to posit some shadowy entity, and this is not to deny either $\mathrm{C} 2$ or $\mathrm{C} 3$. It is just to deny $\mathrm{C} 1$ : that all truthbearers are related to the things they are about.

A consequence of this is that aboutness is not always a relation. Sometimes truthbearers are not related to the things they are about. "But," as Crane states, "to say this is not to say that no thoughts [and no truthbearers] involve relations to real existing things; it is just to say that not all of them do" (ibid.: p. 26). Often our thoughts and truthbearers are about things that exist, such as Barack Obama or this very sentence. In such cases, the truthbearers are related to the things they are about. In other cases, the intentional objects that they are about do not exist, such as Pegasus or Zeus. Thus, sometimes truthbearers stand in A- REL to their intentional objects, that is, when they exist and are real; sometimes truthbearers do not stand in A- REL to their intentional objects.

\subsection{SAC and the explanation of falsity and truth as the failure and satisfaction of aboutness (respectively)}

One way to understand this more clearly is by using an important notion: the notion of aboutness-satisfaction ${ }^{46}$ or aboutness-success. ${ }^{47}$ I think that we can understand the existence or presence of the relation between truthbearer and truthmaker as a satisfaction (or success) of aboutness. In the cases where the intentional objects of the truthbearers exist and are real, the truthbearers are related to the things they are about. Here, there is a satisfaction of the aboutness of these truthbearers. If none of the putative intentional objects of the truthbearer in fact exist and are real, then the truthbearers are not related to those putative objects. In this case, there is no satisfaction of aboutness. Searle, who also employs the notion of satisfaction, would say that in that case, the truthbearers are not about anything at all, even though they might seem to be about something (see [1983: p. 17]). For our purposes, it is enough to think that truthbearers can be about their intentional objects even if those objects do not exist,

\footnotetext{
46 Searle (1983:p. 17) introduces the notion of satisfaction in a similar context. According to Searle, intentional states or truthbearers can have propositional or representational content or meaning, which can fix what they can be about. But unless the entities exist and are real, the truthbearer or intentional state is not satisfied. He writes, "[I]f there is no object that satisfies the propositional or the representative content, then the speech act and the Intentional state [and the truthbearer] cannot be satisfied" (ibid.). My understanding of aboutness-satisfaction does not commit us to the existence of propositional content which needs to be satisfied for there to be aboutness. Aboutness and aboutness-satisfaction do not depend on propositional content or sense, or other related notions.

47 Ceusters and Smith explain, "'being about' is a success verb” (2015:p. 3). According to them, success occurs only in cases of aboutness targeting "portions of reality" (ibid.).
} 
but when what they are about exists, then the truthbearers are satisfied (or successful) in regard to their aboutness. Aboutness-satisfaction marks the presence of an A- REL.

One should understand T-REL in the same way. When the intentional objects of the truthbearer exist and are real and the truthbearer is about ways that these objects really are, then there is not just an A- REL going in the direction from the truthbearer to the truthmaker, but there is a T-REL going in the direction from the truthmaker to the truthbearer.

To make the connection between T-REL and A-REL via aboutness-satisfaction clearer, it's useful to contrast it with what I'll call partial aboutness-satisfaction. It is an important detail that a truthbearer is often not just about real and existing objects, but also about (putatively) real ways these objects are (how things are with the object). A truthbearer which is about an existing and real object can also be false of that object in some way. But, in so far as it is also about how things really are with the object, the truthbearer is at least partially true of that object. For instance, 'Quacky is a small duck' is false but partially true in that she's a duck, albeit a decidedly large one. In Sect. 4.2.4, I explained that partial aboutness is not satisfactory for T- REL and argued that fullness in regard to aboutness is important for T-REL; in the example, for the truthbearer to be true, Quacky must be a small duck, not just either a duck or small. Here, we can make clear that what we need is not partial aboutness-satisfaction but ( strict and full) aboutness-satisfaction.

The parallel between T- REL and A- REL extends to cases where there is no aboutnesssatisfaction, or to put it another way, there is a failure of aboutness-satisfaction. When there is no relation, and the truthbearer in question is not about anything real or existing, while at the same time it is committed to the existence and reality of some thing, then the truthbearer is, strictly speaking, false. ${ }^{48}$ The truthbearer is neither satisfied in terms of aboutness nor is it satisfied in terms of truthmaking. ${ }^{49}$

\footnotetext{
48 In fictional contexts things get complicated. Although it is clear that T4 and T5 are false, what might one say about a truthbearer which states that Sherlock Holmes smokes pipes, not electronic cigarettes? One might say that on the truthmaker-analysis, all truthbearers about fictions are false since Sherlock Holmes does not and has never existed. But the right answer, I propose, really depends on what the right SEM- TAC of truthbearers about fictions is, and it also depends on the nature of fictional entities. For instance, fictional truthbearers might best be understood as talk about texts and what so and so author wrote, rather than about a certain sort of entity which we might call fictional entities, such as fictional people.

49 Remember, I take these to go hand-in-hand (Sect. 4). Truthmaking is a dual relation to aboutness; they are complementing asymmetric relations which go in opposite directions. See van Fraassen (1969: p. 481). However, sub-sentential aboutness present at the level of words indicates that truthmaking and aboutness come apart at the sub-sentential level. Instead, they are complementing at the sentential level. Where there is aboutness-satisfaction at the sentential level, there is truthmaking-satisfaction as well. Sentential-level aboutness, however, should not be taken to be a separate kind of aboutness. I am neutral about the nature of truthmakers. The right account of truthmakers must be approached piecemeal and depends inevitably on what the best SEM- TAC says truths are about. This also makes me agnostic about whether there must be A-RELs and T-RELs at the sentential level that are not reducible to the relations at the sub-sentential level. For instance, the sentential level A- RELs and T-RELs might be plural relations, composed of sub-sentential A- RELs and T- RELs. See Dodd (2002:pp. 74 and 75; 2007:p. 398) for a discussion of what he calls "sub-sentential language/world relations" (ibid.). Dodd (2002: pp. 78-81) argues that these sub-sentential-level relations make it that we do not need to posit any sentential-level entities to play the truthmaker-role. Although I remain agnostic about this, I think that the duality of T- REL and A- REL is strengthened by this consideration. For sentential-level aboutness can easily be understood in terms of sub-sentential-level aboutness. We can easily understand 'the table is round' being about the table
} 
Now that we have introduced the notions of aboutness-satisfaction and -failure, and tied them to truth and truthmaking, we can formulate an understanding of truth and falsity in SAC-ist terms. Falsehood on the SAC-account is the non-satisfaction or failure of strict and full aboutness:

FALSEHOOD-SAC (F-SAC): A truthbearer which positively describes things to be a certain way is false iff the truthbearer fails to be strictly and fully about anything that is really the way(s) it is described to be. ${ }^{50}$

What the truthbearer is about, when what it is about exists and is real, is (or are) its truthmaker(s). Conversely, if instead of failure there is aboutness- satisfaction, then there is truth:

TRUTH-SAC (TR-SAC): A truthbearer is true if it is strictly and fully about things that exist and are real, and it is about how things actually are with those things. ${ }^{51}$

\section{The SAC-ist solution to the problem of negative truths}

Now that we have the SAC-machinery in place, we can address P-NEG. As Russell implies in his criticism of Demos (Russell 1918: p. 213), a theory of negative truths is also a theory of falsehood. As we saw in Sect. 4.4, SAC can give us a theory of falsehood in terms of aboutness-satisfaction failure, namely F-SAC. With F- SAC, we get an answer to the problem of intentionality. We can explain the falsity of T4 (Pegasus exists) and T5 (Zeus exists) in terms of their failure to be about anything that exists or is real. T4 and T5 are positive falsehoods. There are also converse truthbearers which are not positive falsehoods but are, rather, negative truths:

T1 (Not-T4): Pegasus does not exist; or equivalently, Not-(Pegasus exists).

T6 (Not-T5): Zeus does not exist; or equivalently, Not-(Zeus exists).

$\mathrm{T} 1$ and $\mathrm{T} 6$ are negative existentials. By contrast, T2 is a negative truth since, as it says, the cat is not on the mat. It is what we might call "a negative predicative truth".

Footnote 49 contiuned

and how things are with the table, specifically its being round. The best SEM- TAC might not take the truthbearer to be about some sentence-level complex entity the table's being round over and above what it is about at the sub-sentential-level, the table and how things are with the table. This underpins my insistence that the SAC account of truthmaking is modest, as there is no requirement that there are facts or states of affairs understood as complex entities that need to play the truthmaker-role; whatever our truthbearers are strictly and fully about will play this role, whether or not these are entities, or, more modestly, entities and how things are with the entities. See Lewis (1999:pp. 204, 206) and Dodd (2002: p. 74).

50 The reason why I put things this way will become clear in the next section where I distinguish between positive and negative truths (and falsehoods). F- SAC concerns only what are called "positive falsehoods" and not negative falsehoods. Negative falsehoods are made false by what are called falsemakers. For example, 'there are no dogs' is false since it is about dogs not existing and there are dogs. Thus, dogs are falsemakers for this truthbearer. I don't need to give a theory of falsemakers. But, the language of strict and full aboutness helps us understand the notion of a falsemaker. Negative truthbearers are fully about some entities not existing (in the case of negative existentials) or some entities not being some way (in the case of negative predications). However, the entities and how things are with the entities which are being denied in the negative part of the truthbearer is what the truthbearer is strictly about. Normally, the entities and how things are with the entities that the negative truthbearers are strictly about but which are denied by their full aboutness are the falsemakers for these truthbearers.

51 In Sect. 5, I explain why TR-SAC should not be expressed by a bi-conditional. 
Recall TR-SAC. The reason why I did not put this in terms of a bi-conditional is because sometimes truths, such as $\mathrm{T} 1$ and $\mathrm{T} 6$, are also not about anything that is real, but they are still true. So, one cannot insert 'only if' into TR-SAC to make it a biconditional, because it is possible for a truthbearer to be true, and for it to be the case that what the truthbearer is about does not exist and is not real. In short, some truths are negative truths. We can clearly distinguish them from positive truths on the basis of what they are about. And they are true for other reasons than that they are related to existing and real beings. Specifically, they are true on the basis that they are not related to those beings! Let me explain.

In the case of $\mathrm{T} 1$ and $\mathrm{T} 6$, the truthbearers are about things that do not exist and are not real, but the truthbearers are also true. But it would seem that according to F- SAC, if they do not exist and are not real, then the truthbearers should be false. However, T1 and T6, and T2, are not fully about things that do not exist and are not real. Rather, T1 and T6 are fully about these things not existing. What should make these truthbearers true is not the positive existence or reality of anything at all, and especially not something negative. Instead, the reason they are true, when they are true, is that what they are in part about does not exist. In SAC terms, they are strictly and fully about certain putative entities not existing. In particular, even if $\mathrm{T} 1$ is strictly about Pegasus, it is only partially about Pegasus. It is fully about Pegasus not existing. For T1 and T6 to be true, the things that they are strictly and partially about need to be how they are described; in these cases, they should not be any way. That is, there should not be a relation between the truthbearers T1 and T6 on one side, and Pegasus and Zeus on the other, or else things would not be how they are described to be. For T2 to be true, what it is strictly and partially about, that is, the cat, should not be some way. It is strictly and fully about the cat not being some way. To think otherwise, and to think that what they are about must be positive, is to misunderstand what these truthbearers are strictly and fully about.

What I shall call the Representationalist would have a hard time expressing this. Her account differs from mine most centrally in her understanding of the consequences drawn from talk about satisfaction. ${ }^{52}$ Searle, who the theorist I am calling "the Representationalist" follows, writes,

\footnotetext{
52 This in turn also has consequences for her answer to P- INT. The Representationalist would accept C1 as I put it above and, instead, would reject $\mathrm{C} 3$; that is, she would reject the claim that some truthbearers are about things which do not exist. If Pegasus does not exist, then there is no "referred-to object", no intentional object, and T4 is not about Pegasus or anything else. However, this is problematic because the whole point, as I understand it, of talking about intentional objects is to be able to point out that Pegasus is the intentional object of truthbearers such as 'John thought about Pegasus'. John is clearly thinking about something; but the thing he is thinking about happens not to exist. The Representationalist clearly thinks that the aboutness of any thought or truthbearer depends on the satisfaction of the referential portion of the representative content, and hence the existence of the A-REL. Crane also points out the infelicity of the Representationalist use of 'intentional' in this regard. If one uses such terms as 'intentional object' and 'intentional state' as Searle, the main Representationalist, does (above), then, as Crane says, "I would have said, with Searle, that all intentional objects exist, but that some intentional states have no intentional objects" (2001:p. 22). But, as he points out, "I would have been at a loss to say what makes this latter class of states [i.e. intentional states concerning things which do not exist] intentional" (ibid.). If a state lacks an intentional object, surely this rules out that that state is intentional. Further, Crane also thinks that his strategy and way of understanding things allows us to understand why T4 and T5 are about different things even though neither of those things exist.
} 
In such cases, just as there is no "referred-to object" of the speech act, so there is no "Intentional object" of the Intentional state: if nothing satisfies the referential portion of the representative content then the Intentional state does not have an Intentional object. [1983: 17]

Ceusters and Smith (2015) are also Representationalists and capture the core of the view well when they say: "an ICE must in every case be about some portion of reality, where the aboutness in question must always be veridical, so that 'being about' is a success verb" (ibid.: p. 3). They contrast ICEs with representations, which "in contrast, [are] required merely to intend to be about something, and this intention might fail (as when a child draws what she thinks of as a unicorn)" (ibid.). ${ }^{53}$ Strictly speaking, according to the Representationalist, T4 and T5 are not about anything, and thus their falsity is explained by their aboutness failure. However, one cannot merely claim that $\mathrm{T} 1$ and $\mathrm{T} 6$ are not about anything in the same way, since they are also true. $\mathrm{T} 1$ and $\mathrm{T} 6$ are about some putative entities not existing. If the Representationalist claims that they are true because $\mathrm{T} 1$ and $\mathrm{T} 6$ are satisfied in terms of aboutness, this seems to be committing her, paradoxically, to the (positive) reality of non-existence. Alternatively, the Representationalist seems forced to say that some truthbearers which are not about anything are nonetheless true. This is counterintuitive and at best awkward.

We can better express ourselves with the broadly Cranean ${ }^{54}$ way of understanding aboutness and intentional objects that I have been sketching so far. T1 and T6 are in part about Pegasus and Zeus (as T4 and T5 are fully about Pegasus and Zeus); Pegasus and Zeus are the intentional objects of T1 and T6 (and T4 and T5). But Pegasus and Zeus do not exist and are not real. They are just intentional objects, in the schematic sense of being what the truthbearers are about. And sometimes the intentional objects of the truthbearers do not exist and are not real. This, I think, fits neatly with a good semantic account of true negative existentials and other negative truths. They are in part about things that do not exist and are not real; they just differ from true positive existentials such as 'Barack Obama exists', in that they are negative existentials and hence claim about those things that they do not exist or that they are not real. Surely, nothing positively existing needs to exist for those kinds of claims to be true. In fact, for those claims to remain true, the things they are about must remain nothings. I take it that this is consistent with what Mumford (2007) says when he tries to persuade his readers of the non-existence of negative facts:

\footnotetext{
53 On their taxonomy, T4 would be both a "Non-referring representational unit (NRU): an RU [representational unit] which, for whatever reason, fails to be about anything" (ibid.:p. 4; and 2010:p. 4) and a "Recognized non-referring representational unit (RNRU): an NRU which was once intended and believed to be about something, but which, as a result of advances in knowledge, is no longer believed to be so" (ibid.). 'Pegasus' is a known NRU (their example is 'Vulcan'), because we now know that whoever used it in the past and intended it to be about something was in error, since there is no portion of reality containing Pegasus (or Vulcan).

54 By 'Cranean', I do not mean to claim that Tim Crane would agree to anything I say here, but I call it thus because in my set-up of aboutness, I mainly follow the theory of intentionality that Crane presents in (2001) but also more recently in (2013).
} 
A fact $[\ldots]$ is taken to be some kind of existent in the world. [...] But [...] can it really be a fact in the world that there is no hippopotamus in the room? This sounds like an absence of a fact, and an absence is nothing at all. [ibid.: p. 46]

Even though this might disappoint those, such as Russell or Barker and Jago, who believe in negative facts and negative entities, there is no need to understand these nothings as non-existent entities, or any entities or objects in a substantial sense. Rather, they are, in the case of the false truthbearers and the negative truths, nothing except the schematic, intentional objects of our thought, of our attention, and of truthbearers. In general, intentional objects are not always real, for instance when aboutness is not satisified, nor do they need to be posited as real existing entities. In fact, especially in the case of negative existentials, they should not be real, existing entities at all. Under the Cranean understanding of 'about', unlike the Representationalist, one does not need to posit the reality of non-existence. Instead, one gets the right result: for their truth, negative truths require things not to be some way; they do not require things to be any way, least of all some mysterious negative way.

SAC shows us how to reject T- M (and Molnar's M4 above) in a way that is not arbitrary. The right SEM- TAC, if the Cranean framework for thinking about intentionality is right, requires merely that we make a distinction between cases where the intentional objects exist and are real, and the cases where they do not exist and are not real. And, it is clear that we can easily distinguish between positive and negative truthbearers in general. The former are used to claim that some thing exists or is some way. The latter are used to claim that some thing does not exist or is not some way.

Further, with this strategy we do not need to posit underlying or fundamental incompatibility facts, as Demos's strategy does according to Russell and as many recent strategies would need to do. For instance, negative truths do not need to be explained in terms of entailments from primary or atomistic truths (in Mellor's moderate case) nor by an ontology of totality facts or essence-facts (in Armstrong and Cameron's ontological strategy). With the alternative strategies, we were left with the dilemma of accepting incompatibility facts or rejecting $\mathrm{T}-\mathrm{M}$ in a rather arbitrary or unexplained way. The SAC-strategy gives us the resources not to have to accept incompatibility facts, and to draw our rejection of T-M along non-arbitrary, aboutness lines. Nonnegative, positive truths are about things that exist and are real, and about how things really are with those things. Negative truths and falsehoods are about things that do not exist or are not real, or they are about real and existing things but claim that they are not some way. It is clear that a negative truthbearer does not require a negative entity to make it true, if we are clear about what we are talking about.

\section{Responses to potential objections}

I now respond to some potential objections. Especially my responses in Sects. 6.1, 6.2.5, and 6.4 are meant to address the worry that negative facts of some unsavoury sort might be being smuggled in under a false passport. ${ }^{55}$

55 I thank one of the anonymous reviewers at Synthese for putting the issue in this colourful way, one that is relevant to the current migration crisis in Europe and the Middle East. 


\subsection{Objection \#1: Higher-order incompatibility?}

One might object that the account of falsehood in terms of the failure of aboutnesssatisfaction, and the account of negative truths being about things not being some way, posit some sort of higher-level incompatibility fact. This, I think, would be to misunderstand what it is to fail in terms of aboutness-satisfaction.

Failing is indeed incompatible with succeeding. But this incompatibility is not what makes anything true (except perhaps truthbearers about their incompatibility). When I claim, for instance, that in the case of $\mathrm{T} 4$, we have a falsehood because of a failure of aboutness-satisfaction, I am not saying that there is something, a failure, which is incompatible with a success of aboutness-satisfaction. When we talk about failings or failures of something, we are saying that something is missing, not that there is a missing. In the same way that $\mathrm{T} 1$ does not require anything to exist (and especially not Pegasus) to be true, but instead relies on some putative thing (namely Pegasus) not existing, truths about failings and failures of something do not require anything to exist to be true. Rather, they require there not to be something. In the case of truthbearers about failures of about-satisfaction such as 'T4 fails to be about anything that exists', there must not be a relation between $\mathrm{T} 4$ and what it is about. To think that this failure requires some incompatibility fact, or some further, higher-level negative fact, would be to misunderstand the account and to misunderstand what truthbearers about failures of aboutness-satisfaction (or about failures of anything) are about.

\subsection{Objection \#2: Does the account make truth and truthmaking disunified?}

One might worry that the accounts that I gave of truth and falsity, and the subsequent strategy for responding to P- NEG, make truth and truthmaking disunified in a way that is both arbitrary and radical. What results, as the objection might go, are different stories about positive falsehoods, negative truths, and positive truths, with nothing unifying them. This seems, further, to go against the aims of any account of truth (or falsity) and of truthmaking. I shall respond to these potential objections in turn.

\subsubsection{Response \#1: the account is not arbitrary, but piecemeal}

First, the account is not arbitrary. In fact, I see no good basis for thinking that a theory of truth must account for all truths in exactly the same way or that a theory of truthmaking must account for all truths in the same way. A unified theory which does this without any costs, would perhaps be more attractive than a disunified theory. However, as the recalcitrance of P- NEG indicates, such a unified theory is not forthcoming.

Any theory which is disunified, of course, must not make arbitrary distinctions. The proposed approach is piecemeal ${ }^{56}$ and allows us to make non-arbitrary distinctions,

\footnotetext{
56 Bernard Williams describes 'piecemeal' as “a term of praise” (2001: p. 119). Schipper (2016) sketches the importance of a contextualist and piecemeal approach to philosophical, as well as social and political, questions more generally.
} 
based on what I take to be plausible grounds, and in a plausible, intuitive way, consisting broadly of two steps:

(Step One): look closely at what the words in a truthbearer mean, and how they contribute to its meaning and what it is about (e.g. via their word order and their cases, which reveal whether the nouns, pronouns, adjectives, etc., in question take, for instance, the nominative or accusative), and

(Step Two): only on the basis of what the truthbearer says about how things are should we accept an account of what makes it true.

If what the truthbearer says and is about does not make any claims or demands on what exists, and/or how things are with what exists, then it seems perfectly reasonable that things do not need to be any way, and, in fact, things should not be the way they are described not to be for those truthbearers to be true.

Thus, it seems perfectly reasonable that there are no truthmakers for those truths. As we have seen, positive and negative claims clearly differ in what they say about how things are or how things are not. It is, therefore, to be expected, that their truth and falsity should also differ according to what they say about how things are and are not. Not only does what makes them true, when they are true, differ depending on what they are about, but whether or not they are made true, or should be made true, by anything at all can differ depending on what they are about. This can be approached in a piecemeal manner by looking closely at what the truthbearers or the parts of the truthbearers are about.

\subsubsection{Response \#2: the strategy is not radical, but conservative}

Second, the strategy is not radical either. This piecemeal or contextual approach to whether or not truthbearers require truthmakers is much more modest and conservative, and hence less radical, than a unified approach that makes the bolder and more extravagant claim that all truths are true in exactly the same way and that all truths must be made true in exactly the same way. The latter approach tries to fit all truths into the same mould and must explain, despite difficulties and despite appearances to the contrary, how this is the case. P- NEG, as I see it, is one of those major difficulties that make it appear that truth is disunified. The more radical approach is one that explains that the appearances are faulty. The more modest, and less radical, approach is one that accepts that the appearances are correct, but explains how TT can accommodate the appearances.

\subsection{3 'Truth' is a success term}

Further, 'truth' is a success term. The property being true is what one might call a "success-property". In this way, one might think of truth as similar to other success terms and properties, such as those involved in the winning of games. Just as there is no unity with regard to winning games, there is no reason to think that truth and truthmaking should have any unity either. It is highly contextual and depends from game to game what the criteria are for winning any particular game. Even within games, there are sometimes many different ways that one can win. For instance, one 
can win at chess either by putting one's opponent in a checkmate position or by putting one's opponent in an impossibly difficult position, not quite checkmate, but one which makes her forfeit the game. Also in backgammon, one can win in different ways. Most standardly one wins by getting one's pieces off the board before one's opponent. But one can also win if one's opponent "drops the stakes," that is, resigns after one has doubled the stakes of the game. In some games, there are no ways to win at all, such as with games that have no criteria for winning (for example, continuous play games such as the game of LIFE or non-competitive Frisbee; they have rules for game-play but no rules for winning). Also, some card games are such that one can win by winning all the chips or tokens in play while others are such that one wins by losing all one's chips or tokens. In the same way as the rules for successfully winning may vary greatly from game to game, it seems that the rules for a truthbearer to succeed at being true might also vary greatly from truthbearer to truthbearer. And it seems perfectly modest and plausible to think that the criteria for truth vary according to what the truthbearers are strictly and fully about. Such disunity is far from radical and seems plausibly commonplace.

\subsubsection{The strategy lets us conserve classical logic}

The SAC-proposal is also less radical than other proposals in other ways. Let me briefly illustrate this with a comparison. Mumford (2007) rejects Molnar's M3 on the basis of giving a "philosophical account" (ibid.: p. 53) of negative truths in terms of equivalent falsehoods, reducing the former to the corresponding instances of the latter. For example, the "correct philosophical account" (ibid.) of 'It is not raining', when true, is nothing more than that 'It is raining' is false. So, he rejects the claim that some negative truths about the world are true by "eliminating all negative truths" (ibid.: p. 51). Mumford (ibid.: §7, pp. 57-58) admits, however, that this solution requires us to revise classical logic, or at least to "reinterpret certain claims in the light of the new equivalences" (ibid.: p. 57). In particular, he thinks that all that we need to do is to understand the law of excluded middle (LEM) in terms of bivalence (BIV). The law is:

LEM: $\forall p(p \vee \neg \mathrm{p})$

If understood in the following way, we are committed to the possibility of negative truths:

LEM*: $\forall p($ true $<p>\vee$ true $<\neg p>)$

This is not acceptable to a view that attempts to eliminate negative truths. Mumford claims he has a principled reason for understanding LEM in terms of BIV, which is:

$$
\text { BIV: } \forall p(\text { true }<p>\vee \text { false }<p>)
$$

However, this seems to me to be a rather radical interpretation, since LEM and BIV are not the same principle and should be understood independently, even if they are equivalent. First, whatever the merits of classical logic, understanding LEM in terms of BIV rules out being able even to express other logics which are not bivalent, but which accept LEM. Second, it is radical because, by contrast, the new, rival strategy will allow us to understand LEM in terms of LEM*, rather than BIV. Mumford (ibid.: 58) 
argues that his interpretation will be able to account for truthbearers about the future better than LEM* $^{*}$. Consider the truthbearer:

P1: There will be a sea battle tomorrow.

Let's say that P1 is neither true nor not true now. According to Mumford, if one accepts LEM*, then "when [one] thought $\neg t[r u e]<p>$, then [one] would have to accept $t[$ rue $]<\neg p>$ " (ibid.). The problem according to him is that there is no truthmaker for $\langle p\rangle$ nor one for $\langle\neg p>$. His suggestion is to understand LEM as BIV, on which $\neg$ true $<p>$ is understood as false $<p>$, which, according to him, doesn't require a truthmaker. The SAC-strategy allows us to avoid the problem he raises for accepting the equivalence of $\neg$ true $<p>$ with true $<\neg p>$, remaining conservative by not having to radically reinterpret LEM as BIV. It does not matter that $\langle\neg p\rangle$ does not have a truthmaker according to SAC, because $\langle\neg p>$ is not a positive claim, and hence does not need one; in fact, one will realise that it should not have a truthmaker, if one understands what it is about. Thus, the SAC account is at least less radical than Mumford's and allows us to interpret laws such as LEM in the standard way.

\subsubsection{Knowing which terms are existence-entailing is essential to understanding what the truthbearers are fully about}

There is also another reason why it is not radical. The distinction between negative truths and positive truths is not the only distinction that can be made on the basis of aboutness and being careful about what exactly truthbearers are strictly and fully about. Consider:

T7: Pegasus is a mythological animal.

and

T7*: Vulcan is a hypothetical planet.

Both $\mathrm{T} 7$ and $\mathrm{T} 7 *$ are true. However, neither Pegasus nor Vulcan exist. Some predicates such as '...is material', '...is an animal', and '...is a planet' are existence-entailing 57 and others such as '... is mythological', '... is a mythological animal', and '... is a hypothetical planet' are not. Plausibly, predicates made up of adjectives such as 'potential', 'putative', 'hypothetical', 'mythological', and 'imaginary' are not existence-entailing; this is why one speaks the truth when one says that the hypothetical object Vulcan does not exist but that the hypothetical and confirmed-to-exist object Neptune does exist. We understand this on the basis of thinking about what kinds of predicates these are, what they mean and are about. Understanding that these predicates are not existenceentailing, and understanding what they say about the things that they are used to talk about, is essential for understanding that these kinds of claims, while positive, also do not require truthmakers.

Knowing which expressions are referential and existence-entailing and which ones are not is an important part of mastering the vocabulary of a language and is important for non-philosophical contexts as much as for philosophical contexts. This is an

57 Priest (2005:p. 64) and Crane (2013:p. 61ff) think that many properties are existence-entailing while many others are not. Examples of existence-entailing properties are: being material, being located in space and time, etc. 
important part of understanding how varied and rich is the toolbox of aboutness apparatuses, which I talked about in Sect. 4.2.1. If Alfred tells little Erik that the Kraken is a mythological, imaginary creature invented to frighten children when they think of the sea, then Erik would be making a mistake if, trusting that Alfred is telling the truth, he were to think, as a result, that the Kraken exists. Specifically, he misunderstands what Alfred is saying, what he is talking about. He does not understand yet that 'mythological, imaginary creature' is not existence-entailing. And knowing this is essential for Erik's understanding of what Alfred is talking about here. Unless Erik comes to understand which terms are existence-entailing and which are not, Erik will not understand either what is said or what is being talked about. The best SEM- TAC and, hence, the best account of TT must respect and accommodate this.

Thus, understanding what we are strictly and fully talking about also helps us to understand which positive truths require truthmakers, and which do not require truthmakers, not just that negative truths do not require truthmakers. This, I think, is a perfectly reasonable way of understanding the connection between what these kinds of truths are about and whether they require truthmakers. Negative truths use the negation connective, 'it is not the case that $\phi$ ', and can be understood in a similar, non-existence-entailing way. Thus, the SAC-strategy for addressing negative truths is just as non-radical as the strategy for understanding other truthbearers, constructed out of such predicates, which are not existence-entailing. For truthbearers that are not existence-entailing, such as negative truths, it would be unreasonable to require that they are made true by things that exist. That would be to misunderstand what they are about. And, this is also why we are not smuggling in negative facts under a false passport. Understanding what 'Pegasus does not exist' is strictly and fully about means understanding that Pegasus must not exist, not that there must be a non-existence of Pegasus. To think otherwise is to misunderstand what we are strictly and fully talking about when we are using 'not' to deny that some putative thing exists.

\subsubsection{Is the strategy Meinongian?}

It is an interesting question to what extent there are similarities between the approach I have sketched and Meinong's. ${ }^{58}$ An in depth discussion of this will, however, have to be left for another time, as it goes beyond the scope of this paper to address this issue properly. Thus, I remain neutral here about whether or not the approach I have sketched is Meinongian and to what degree there are similarities or overlap with the subtle and important distinctions Meinong made between the various categories of object in especially his mature Gegenstandstheorie, the theory of intentional objects. ${ }^{59}$

However, it is worthwhile to say something about the similarities and differences. There are interesting similarities, for instance, between Meinong's mature doctrine of the Außersein of "pure objects" and my treatment of talk about mythological crea-

\footnotetext{
58 I thank an anonymous reviewer for spurring me on to write this section as a response to very interesting comments about Meinong.

59 See especially (Jacquette 2015: §4) for crucial differences between the early and mature versions of his theory. Jacquette calls Gegenstandstheorie "the theory of intended objects"(ibid.: p. 1).
} 
tures. ${ }^{60}$ In particular, it is their Außersein, their essential constitutive properties which they have whether or not they exist, which distinguishes nonexistent intentional objects such as the golden mountain from similarly nonexistent intentional objects such as the largest six-winged, peach-coloured horse and from existent intentional objects such as Big Ben. The Außersein of an object is its indifference to being and non-being, and underlies the famous Meinongian principle of the independence of Sosein from Sein: in short, that an object can have properties ( Sosein) without having being ( Sein). ${ }^{61}$ Because an object need not have being to have properties and what Meinong calls a "proper essence" (ibid.), ${ }^{62}$ we can, for instance, distinguish between the golden mountain and the largest six-winged, peach-coloured horse. For one, the latter is six-winged while the former is not. In this way, Meinong gives a detailed and important account of the way in which we can distinguish between nonexistent intentional objects.

Although it is, as I have pointed out earlier, important to be able to distinguish between nonexistent intentional objects, it is unclear that I would have to subscribe to the Meinongian distinctions and categories to do so. First, nothing that I have said so far commits me to the claim that objects do not have to exist to be certain ways. In fact, the strategy sketched in the paper is consistent with thinking that objects cannot be any way, if those objects do not exist. Talking about the Kraken is different from talking about Pegasus. However, talking about something does not carry any ontological commitments, that is, something does not have to be real to be the object of conversation, talk, or thought. Rather, talking truly about things while using existenceentailing predicates does. Given that '...has wings' is an existence-entailing predicate, one cannot truly claim, for instance, that one way to draw a distinction between Pegasus and the Kraken is that the former has wings while the latter does not. Since Pegasus is a mythological creature, he, just like the Kraken, cannot have wings. For being winged requires a body to which the wings are connected. And since having a body requires existence, being winged also requires existence. ${ }^{63}$ According to Meinong, however, Außerseiende objects such as Pegasus, the Kraken, and the King of France do have properties such as, respectively, being winged, being a sea dragon, and being a king. In fact, they have these properties essentially and constitutively. The account that I have sketched does not require this.

Second, although it is true that being an intentional object (and hence being the object of talk and thought) is ontologically neutral (see Sect. 4.3), and in that sense outside of being and non-being, it is unclear that we need to subscribe to Meinong's sense of Außersein. As Lambert explains, Außersein is a metaphysical notion and captures the claim that "what an object is [is] a function solely of its nature. It is

\footnotetext{
60 See especially Meinong (1969-1978; II, §4). Außersein (literally, outside-being) is described as going beyond both being and non-being (Meinong 1904/1960: p. 86). This is contrasted with and argued to be an improvement on Quasisein, which is a category of beingless or almost-being objects. See (Jacquette 2015: $\S 4)$ for further discussion.

61 This principle was first formulated by his student Ernst Mally (1904: p. 127).

62 According to Meinong, this proper essence "subsists in its Sosein" (ibid.).

63 This kind of point is also made several times, with several examples, by Crane (2013: pp. 62-64) in a discussion where he is also distinguishing between his view and that of Meinong and Meinongian noneists such as Priest (2005) and Routley (1980).
} 
in virtue of their natures that camels have humps, the number one is prime, and Mill's round square is round" (1983: p. 17). The approach that I have sketched can remain modest and be ontologically neutral about there being essences or natures of things. Even though we can talk about Pegasus and also talk about something else, the Kraken, that we're talking about these different things does not require us to have any commitments about their essences or natures. When asked to say more about the differences between the Kraken and Pegasus, one may say further true things such as 'The Kraken is a mythological sea dragon while Pegasus is a mythological winged horse and not the other way around'. What one has said is true, and since it is not existence-entailing (for neither the predicates '....is a mythological sea dragon' nor '...is a mythological winged horse' is existence-entailing), it carries no commitments to what exists. Most importantly for our current discussion, it carries no consequences for what the natures of these intentional objects are. In fact, as I have explained (Sect. 6.2.5), the Kraken and Pegasus, being mythological creatures, are importantly not real. And it is plausible that things that are not real do not have essences or natures. Meinong's account of Außersein attempts to give us the deep story about what is going on with intentional objects and their natures. But, the modest strategy that I have sketched takes part of its modesty from the fact that intentional objects are just the schematic objects of attention (see Sect. 4.3). There is no need for a deeper story about the nature of intentional objects, neither when they are merely intentional objects nor when they are truthmakers. Even if Meinong's Außersein gives us the correct deep, metaphysical story of the nature both of intentional objects and truthmakers, it will be the task of further inquiry to convince me of this, as I see no reason to think that the current strategy requires any such metaphysically rich notions.

Of course, there is much else to say about Meinong, Meinongians, and both how the current strategy I have sketched differs from and overlaps with other strategies and accounts. However, I feel that I have, for now, said enough to present some potential differences between the current strategy and what Meinong and Meinongians have claimed.

\subsection{Objection \#3: Does the SAC understanding of TT reject everything the TT-ist holds dear?}

The third objection is that understanding TT in this piecemeal and disunified way rejects everything that TT-ists hold dear. The worry might be that the SAC account is no longer a version of TT, if it allows that so many truths, all negative truths and even some positive truths, do not have truthmakers.

My response is that a modest version of TT, which respects what we say and what we are talking about when using truthbearers, is a more plausible version of TT, whose main aim is to elucidate and say true things about the relation between truths and reality. If it turns out that many truths do not have a relation to reality, and in fact, given what they say and are about, require there not to be a relation with reality, then the version of TT which identifies and captures this is a better version of TT than the alternatives, which claim that there is a relation when there is not. SAC identifies when there is indeed a relation between truths and reality, and modestly and correctly, refuses 
to claim that there is such a relation when there should not be. The way that SAC does this is by telling us to look closely at what our truthbearers are strictly and fully about. And, we are clearly still TT-ists, because we claim that there is a large subset of truths that require there to be truthmakers for them to be true, even though there are many truthbearers which do not require truthmakers to make them true. Happily, we restrict the need for truthmakers and reject Maximalism in a non-arbitrary way.

\subsection{Objection \#4: Does the truth of logical laws and analytic truths go against SAC?}

A fourth general objection might go thus. Recall my point in response to Mellor's strategy of appealing to the laws of non-contradition and excluded middle, which I considered to be re-describing Demos's incompatibilities as laws of logic. I wrote, following Russell, that the truth of logical laws requires as much explaining as the truth of anything else. However, one might take logical truths and also broadly analytic truths to be counterexamples to SAC. One might think, for instance, that truths concerning logical laws are true in virtue of the meanings of the logical constants, and, likewise, that broadly analytical truths are true in virtue of the meanings of the non-logical terms in them. Thus, what explains these truths is not what they are about, but something else. For instance, LEM seems to be true merely because of the meaning of the logical constants and independently of any assignments given to the variable. And, 'bachelors are unmarried men' is true merely because of the underlying complex linguistic behaviours and conventions which fix the meanings of 'bachelors' and 'unmarried men' and 'are', rather than what they are about.

First, a general response. The piecemeal aspect of the SAC-strategy does not rule out that there are possible exceptions to the claim that truths are made true by what they are strictly and fully about. Perhaps the nature of such truths can explain why they are exceptions. However, one of the reasons why the approach to negative truths wasn't arbitrary was because there was a non-arbitrary fact about truthbearers, which are semantic constructions: negative truths have aboutness features which can explain why they don't need truthmakers to be true. The aboutness features of logical and analytical truths don't seem to be similarly explanatory. Or are they?

Let's first look at analytic truths, such as 'bachelors are unmarried men'. Indeed, one explanation for why such analytic truths are true is that there is something about the conventions which fix their meanings in virtue of which they are true. However, another explanation for their truth is that things are the way they are described to be. Bachelors are, indeed, unmarried men. Knowing linguistic usage and conventions is perhaps sufficient for knowing the truth of such analytic claims, but they do not determine the truth in the way that their truthmakers do. Whether things are the way they are described, whether what they are strictly and fully about is how things are, determines the truth of these claims in the appropriate truthmaking way.

The truths of logical laws are a bit more tricky and the correct response will inevitably depend on what the best SEM- TAC says about them. Perhaps these truths are just truths about logical laws, that is, the best SEM- TAC might give an account of statements of logical laws, such as LEM above, as statements about the relevant logi- 
cal laws. If this is the case, then the logical laws, as what such truthbearers are about, would make true such statements, in the same way as perhaps the laws about brakeless trains make true the truthbearers in Sect. 4.1. These logical laws and brakeless train laws are just what the best SEM-TAC will say that the corresponding truthbearers are about. The truthmakers for such laws will not be the meanings of logical constants. Rather, the meanings of the logical constants will reflect the reality concerning logical laws which they are used to talk about. This reality is both what these truthbearers are about and what makes them true. ${ }^{64}$

\subsection{Objection \#5: Does SAC rule out alien truthmakers?}

The final objection which I would like to consider is this. Armstrong (2004:p. 88) argues that alien truthmakers must be not just epistemically but metaphysically possible. That is, it must be possible for there to be alien truthmakers, properties and relations which are not actually instantiated nor combinatorially constructible out of actually instantiated properties or relations. He argues there that the existence of such aliens is a "genuine possibility, although, of course, a mere possibility" (ibid.). One might argue that SAC rules out the very possibility of alien truthmakers. And, then, on the assumption that Armstrong is right about aliens, one might conclude that SAC gets us the wrong result about them, and thus must be rejected. ${ }^{65}$

My response is that I don't see how this argument would go. SAC doesn't rule out alien truthmakers. As with negative truths, we would have to address modal truths in a piecemeal way. Nothing I have said about SAC in this paper addresses what the right account of modal truths is. My general answer to anyone who demands that I give an account of the truthmakers of modal truths would be: let's see what SAC and the best SEM-TAC say modal truths are about. Once we have the best account of what they are about, we also have an account of their truthmakers. Consider 'It is possible that I raise my left arm after I finish typing this sentence'. The truthbearer is about the possibility that I raise my left arm after I finished typing that sentence. Let's say that a combinatorialist [such as Armstrong (1989)] is right. Then, what that possibility amounts to is a combination of various properties which are actually instantiated. If a dispositionalist about possibilities is right (see, for instance, Martin 2008: pp. 2933 ), then the truthbearer is about the disposition I had of raising my left arm in that circumstance.

But what about alien properties? Consider 'Alien properties are merely possible' or 'It is possible that I may instantiate some alien property'. Both of these truthbearers are strictly about alien properties and fully about alien properties and their being possible in the first case, and my possibly instantiating them, in the second. If alien properties are indeed possible, and if it is indeed possible that I instantiate an alien property, then these facts, whatever they are fundamentally or whatever metaphysical account

\footnotetext{
64 I thank one of my anonymous reviewers at Synthese for pressing me to reveal what SAC says the truthmakers of analytic truths and of truths about logical laws are.

65 I thank the same anonymous reviewer as before for hinting at this potential objection.
} 
of modal facts is the correct one, will be the truthmakers for these modal truths about aliens. Therefore, SAC does not rule out alien truthmakers.

\section{Conclusion}

Finally, it should be clear that we are able to avoid positing any sort of ontologically repugnant things which must exist to make negative claims true. There are no entities that are smuggled in through a false passport-in fact there are no entities at all that make true negative truths, and given SAC, that's exactly how it should be. For it would be to misunderstand what these negative truths are about to think otherwise.

In conclusion, the version of TT which respects and incorporates strict and full aboutness can give us a strategy for addressing the problem of negative truths in a non-arbitrary, intuitive, and modest way.

Acknowledgements I thank most especially Paul Snowdon for his profound wisdom and for constantly encouraging me to develop my ideas. Tim Crane was also a great inspiration. Leiden University's Theoretical Philosophy Cluster heard a short version of this paper. I thank all present, especially Göran Sundholm, Maria van der Schaar, Frank Chouraqui, Victor Gijsbers, Bruno Verbeek, Tim Meijers, and James McAllister for helpful questions and reactions. I also thank Alex Steinberg, Katharina Felka, Stephen Yablo, Daniel Rothschild, Mark Jago, and Kit Fine, for stimulating discussions in Hamburg, August 2015. Finally, I thank the anonymous referees and the editor of Synthese for many constructive comments. Conflict of Interest: The author declares that he has no conflict of interest.

Open Access This article is distributed under the terms of the Creative Commons Attribution 4.0 International License (http://creativecommons.org/licenses/by/4.0/), which permits unrestricted use, distribution, and reproduction in any medium, provided you give appropriate credit to the original author(s) and the source, provide a link to the Creative Commons license, and indicate if changes were made.

\section{References}

Anscombe, G. E. M. (1965). The intentionality of sensation: A grammatical feature. In R. J. Butler (Ed.), Analytical philosophy: 2nd series (pp. 158-180). Oxford: Blackwell.

Armstrong, D. (1969). Dispositions are causes. Analysis, 30(1), 23-26.

Armstrong, D. (1983). What is a law of nature?. Cambridge: Cambridge University Press.

Armstrong, D. (1989). A combinatorial theory of possibility. Cambridge: Cambridge University Press.

Armstrong, D. (1997). A world of states of affairs. Cambridge: Cambridge University Press.

Armstrong, D. (2004). Truth and truthmakers. Cambridge: Cambridge University Press.

Asay, J. (2011). Truthmaking, truth, and realism: New work for a theory of truthmakers. Ph.D. Dissertation, University of North Carolina, Chapel Hill.

Austin, J. L. (1946). Other minds. In J. O. Urmson \& G. J. Warnock (Eds.), (1970) Philosophical papers (2nd ed., pp. 76-116). Oxford: Oxford University Press.

Austin, J. L. (1962). How to do things with words. Oxford: Oxford University Press.

Barker, S., \& Jago, M. (2012). Being positive about negative facts. Philosophy and Phenomenological Research, 85(1), 117-138.

Beebee, H., \& Dodd, J. (Eds.). (2005). Truthmakers: The contemporary debate. Oxford: Oxford University Press.

Berto, F. (2013). Existence as a real property: The ontology of meinongianism. Dordrecht: Springer Science+Business Media.

Bigelow, J. (1988). The reality of numbers: A Physicalist's philosophy of mathematics. Oxford: Clarendon Press.

Bigelow, J. (1996). Presentism and properties. In J. E. Tomberlin (Ed.), Philosophical perspectives, 10, metaphysics (pp. 35-52). Cambridge: Blackwell. 
Black, M. (1993). More about metaphor. In A. Ortony (Ed.). (1993), pp. 19-41; modified reprint of Black (1977). More about metaphor. Dialectica, Vol. 31, Fasc. 3-4: pp. 43-57.

Brogaard, B., \& Smith, B. (2000). A unified theory of truth and reference. Logique et Analyse, 169-170, 49-93.

Cameron, R. (2005). Truthmaker necessitarianism and maximalism. Logique et Analyse, 48(189-192), 43-56.

Cameron, R. (2008a). Truthmakers and ontological commitment: Or how to deal with complex objects and mathematical ontology without getting into trouble. Philosophical Studies, 140, 1-18.

Cameron, R. (2008b). How to be a truthmaker maximalist. Noûs, 42(3), 410-421.

Cameron, R. (2008c). Truthmakers, realism and ontology. Royal Institute of Philosophy Supplement, 62, $107-128$.

Cameron, R. (2008d). Comments on Merricks's truth and ontology. Philosophical Books, 1(4), $292-301$.

Cameron, R. (2010a). How to have a radically minimal ontology. Philosophical Studies, 151, 249-264.

Cameron, R. (2010b). Quantification, naturalness and ontology. In A. Hazlett (Ed.), New waves in metaphysics (pp. 8-26). Basingstoke: Palgrave MacMillan.

Ceusters, W. (2012). An information artifact ontology perspective on data collections and associated representational artifacts. In Mantas et al. (Eds.), Quality of life through quality of information, IOS Press, pp. 68-72. doi:10.3233/978-1-61499-101-4-68. Accessed May 31, 2016.

Ceusters, W., \& Smith, B. (2015). Aboutness: Towards foundations for the information artifact ontology. ICBO 2015. http://ncor.buffalo.edu/2015/icbo-aboutness.pdf.

Crane, T. (2001). Elements of mind: An introduction to the philosophy of mind. Oxford: Oxford University Press.

Crane, T. (2013). The objects of thought. Oxford: Oxford University Press.

de Bretton Platts, M. (1997). Ways of meaning: An introduction to philosophy of language. Cambridge: MIT Press.

Demos, R. (1917). A discussion of a certain type of negative proposition. Mind, 26(102), 188-196.

Dodd, J. (2002). Is truth supervenient on being? Proceedings of the Aristotelian Society, 102, 69-86.

Dodd, J. (2007). Negative truths and truthmaker principles. Synthese, 156, 383-401.

Dunn, J. M. (1996). The Algebra of Intensional Logics. Ph.D. Dissertation, Pittsburgh University.

Fine, K. (2001). The question of realism. Philosophers' Imprint, 1(1), 1-30.

Fine, K. (2015a). A theory of truth-conditional content II: Subject-matter, common content, remainder and ground. Published online: https://www.academia.edu/9206919/Truthconditional_Content_-_Part_II. Accessed 18 July 2015.

Fine, K. (2015b). Yablo on subject-matter. Published online: https://www.academia.edu/15555407/Review_ of_Steve_Yablos_Aboutness. Accessed 15 Aug 2015.

Forrest, P., \& Khlentzos, D. (2000). Introduction: Truth maker and its variants. Logique et Analyse, 43(169170), 3-15.

Fox, J. (1987). Truthmaker. Australasian Journal of Philosophy, 65(2), 188-207.

Goldman, A. (1977). Perceptual objects. Synthese, 35(3), 257-284.

Gorman, M. (2006). Talking about intentional objects. Dialectica, 60(2), 135-144.

Gregory, D. (2001). Smith on truth-makers. Australasian Journal of Philosophy, 79, 422-427.

Hale, B., \& Wright, C. (2009). The metaontology of abstraction. In D. J. Chalmers, D. Manley, \& R. Wasserman (Eds.), Metametaphysics: New essays on the foundations of ontology (pp. 178-212). Oxford: Oxford University Press.

Hammond, M., Howarth, J., \& Keat, R. (1991). Understanding phenomenology. Cambridge: Basil Blackwell.

Heil, J. (2000). Truth making and entailment. Logique et Analyse, 43, 231-242.

Husserl, E. (1970). Logical investigations, revised edition. Translated by J. N. Findlay, New York: Humanities Press.

Jacquette, D. (2015). Alexius Meinong, the shepherd of non-being. Dodrecht: Synthese International Publishing.

Jago, M. (2011). Setting the facts straight. Journal of Philosophical Logic, 40, 33-54.

Jago, M. (2012). The truthmaker non-maximalist's dilemma. Mind, 121(484), 903-918.

Jago, M. (2013). The cost of truthmaker maximalism. Canadian Journal of Philosophy, 43(4), 460-474.

Johnson, W. E. (1924). Logic, part III. Cambridge: Cambridge University Press.

Kant, I. (1784). An answer to the question: 'What is enlightenment?. In Kant (1970). Kant: political writings, H. S. Reiss (Ed.). Cambridge: Cambridge University Press, pp. 54-60. 
Kirkham, R. L. (1992). Theories of truth: A critical introduction. Cambridge: MIT Press.

Kukso, B. (2006). The reality of absences. Australasian Journal of Philosophy, 84(1), 21-37.

Lambert, K. (1983). Meinong and the principle of independence: Its place in Meinong's theory of objects and its significance in contemporary logic. Cambridge: Cambridge University Press.

Lewis, D. (1999). Armstrong on combinatorial possibility. In Papers in Metaphysics and Epistemology. Cambridge: Cambridge University Press, pp. 196-214; originally published as (1992). Critical notice of D. M. Armstrong's A combinatorial theory of possibility. Australasian Journal of Philosophy, 70(2), 211-224.

Lewis, D. (2001). Truthmaking and difference-making. Noûs, 35, 602-615.

Lewis, D. (2003). Things qua Truthmakers. In H. Lillehammer \& G. Rodriguez-Pereyra (Eds.), (2003). Real Metaphysics: Essays in Honour of D. H. Mellor (pp. 25-38). London: Routledge.

Linsky, B. (1994). Truth maker for modal propositions. The Monist, 77(2), 192-206.

MacBride, F. (2014). Truthmakers. The stanford encyclopedia of philosophy (Spring 2014 Edition), E. N. Zalta (Ed.). http://plato.stanford.edu/archives/spr2014/entries/truthmakers/. Accessed 10 Jan 2015.

Mally, E. (1904). Untersuchungen zur Gegenstandstheorie des Messens. In Untersuchungen zur Gegenstandstheorie und Psychologie, vol. III, A. Meinong (Ed.), pp. 121-162. Leipzig: Verlag von Johann Ambrosius Barth.

Martin, C. B. (1980). Substance substantiated. Australasian Journal of Philosophy, 58(1), 3-10.

Martin, C. B. (1996). How it is: Entities, absences and voids. Australasian Journal of Philosophy, 74, 57-65.

Martin, C. B. (1997). On the need for properties: The Road to pythagoreanism and back. Synthese, 112, $193-231$.

Martin, C. B. (2008). The Mind in Nature. Oxford: Oxford University Press.

McCulloch, G. (1994). Using sartre: An analytical introduction to early sartrean themes. London: Routledge.

McIntyre, R., \& Smith, D. W. (1982). Husserl and intentionality: A study of mind, meaning, and language. Dordrecht: D. Reidel Publishing Company.

Meinong, A. (1904/1960). Über Gegenstandstheorie. In A. Meinong (Ed.), Untersuchungen zur Gegenstandstheorie und Psychologie. Leipzig: J. A. Barth, pp. 1-51; Chisholm (trans.) (1960). The theory of objects. In R. Chisholm (Ed.), Realism and the background of phenomenology. New York and London: The Free Press Collier Macmillan, pp. 76-117.

Meinong, A. (1969-1978). Alexius Meinong Gesamtausgabe. I-VIII, R. Haller \& R. Kindinger (Eds.), in collaboration with Roderick M. Chisholm. Graz: Akademische Druck- u. Verlagsanstalt.

Melia, J. (2005). Truthmaking without truthmakers. In H. Beebee \& J. Dodd (Eds.), (2005), pp. 67-84.

Mellor, D. H. (2003). Replies. In H. Lillehammer \& G. Rodriguez-Pereyra (Eds.), Real metaphysics: Essays in honour of D. H. Mellor (pp. 212-238). London: Routledge.

Mellor, D. H. (2012). Truthmakers for what?. Initially in H. Dyke, (Ed.). (2009). From truth to reality: New essays in logic and metaphysics. New York: Routledge, pp. 272-90, reprinted and revised in Mellor (2012). Mind, meaning, and reality, (pp. 96-112), Oxford: Oxford University Press.

Merricks, T. (2007). Truth and ontology. Oxford: Clarendon Press.

Milne, P. (2005). Not every truth has a truthmaker. Analysis, 65(287), 221-224.

Molnar, G. (2000). Truthmakers for negative truths. Australasian Journal of Philosophy, 78(1), 72-86.

Moretti, L. (2006). The tacking by disjunction paradox: Bayesianism versus hypotheticodeductivism. Erkenntnis, 64(1), 115-138.

Mulligan, K., Smith, B., \& Simons, P. (1984). Truth-makers. Philosophy and Phenomenological Research, 44 (3); reprinted in E. J. Lowe \& A. Rami (Eds.), (2009). Truth and truth-making. Stocksfield: Acumen Publishing Ltd., and Montreal: McGill-Queen's University Press, pp. 59-86.

Mumford, S. (2005). The true and the false. Australasian Journal of Philosophy, 83(2), 263-269.

Mumford, S. (2007). Negative truth and falsehood. Proceedings of the Aristotelian Society, 107(1pT1), $45-71$.

Oliver, A. (1996). The metaphysics of properties. Mind, 105, 1-80.

Parsons, J. (2005). Truthmakers, the past, and the future. In H. Beebee \& J. Dodd (Eds.), (2005), 161-174. Parsons, J. (2006). Negative truths from positive facts? Australasian Journal of Philosophy, 84(4), 591-602. Priest, G. (2005). Towards non-being. Oxford: Oxford University Press.

Quine, W. V. O. (1960). Word and object. Cambridge: MIT Press.

Ramsey, F. P. (1927). Facts and propositions. In Proceedings of the Aristotelian Society, 7 (Supplementary): 153-170; reprinted in Ramsey (1978). Foundations: Essays in philosophy, logic, mathematics and economics. D. H. Mellor (Ed.), London and Henley: Routledge \& Kegan Paul, pp. 40-57. 
Read, S. (2012). Necessary truth and proof. In M. Marion, G. Primiero, \& S. Rahman (Eds.), The realismantirealism debate in the age of alternative logics, logic, epistemology, and the unity of science (Vol. 23, pp. 251-267). Dordrecht: Springer Science+Business Media B.V.

Restall, G. (1996). Truthmakers, entailment and necessity. Australasian Journal of Philosophy, 74(2), 331340.

Rodriguez-Pereyra, G. (2006). Truthmakers. Philosophy Compass, 1(2), 186-200.

Routley, R. (1980). Exploring Meinong's jungle and beyond (interim ed.). Canberra: Australian National University.

Russell, B. (1905). On denoting. In Russell (1956), 39-56.

Russell, B. (1918). The philosophy of logical atomism. In Russell (1956), 175-282.

Russell, B. (1919). On propositions: What they are and how they mean. In Russell (1956), 283-320.

Russell, B. (1956). Logic and knowledge. Nottingham: Russell Press Ltd.

Russell, B. (1961). My philosophical development. The basic writings of Bertrand Russell (pp. 9-22). London: George Allen \& Unwin.

Russell, B. (1993). Descriptions. In A. W. Moore (Ed.), Meaning \& Reference (pp. 46-55). Oxford: Oxford University Press.

Sartre, J.-P. (1956). Being and nothingness: A phenomenological essay on ontology. H. Barnes (trans.), New York: Washington Square Press.

Schaffer, J. (2004). Causes need not be physically connected to their effects: The case for negative causation. In C. R. Hitchcock (Ed.), Contemporary debates in philosophy of science (pp. 197-216). Oxford: Basil Blackwell.

Schipper, A. (2016). Review of Dialectics in World Politics. In S. Brincat (Ed.), Marx and Philosophy Review of Books, 2227, 29 February, accessible online: http://marxandphilosophy.org.uk/reviewofbooks/ reviews/2016/2227.

Searle, J. (1983). Intentionality: An essay in the philosophy of mind. Cambridge: Cambridge University Press.

Simons, P. (2000). Truth-maker optimalism. Logique et Analyse, 43(169-170), 17-41.

Simons, P. (2005). Negatives, numbers, and necessity: Some worries about Armstrong's version of truthmaking. Australasian Journal of Philosophy, 83(2), 253-261.

Simons, P. (2008). Why the negations of false atomic sentences are true. Essays on Armstrong. Acta Philosophica Fennica, 84, 15-36.

Smith, B. (1999). Truthmaker realism. Australasian Journal of Philosophy, 77, 274-291.

Smith, J. F. (1985). The Russell-Meinong debate. Philosophy and Phenomenological Research, 45(3), 305-350.

Sorensen, R. (2008). Seeing dark things: The philosophy of shadows. Oxford: Oxford University Press.

Strawson, P. F. (1972). Language and creativity. Professor Strawson and Gareth Evans discuss linguistic theory in this part of Logic Lane, a series of films on Oxford philosophy by Michael Chanan. Available online: http://youtu.be/u_vGj9BuY18.

van Fraassen, B. (1969). Facts and tautological entailment. The Journal of Philosophy, 66(15), 477-487.

van der Schaar, M. S. (2011). The cognitive act and the first-person perspective: An epistemology for constructive type theory. Synthese, 180, 391-417.

Williams, B. (2001). The spell of linguistic philosophy. In B. Magee (Ed.), Talking philosophy: Dialogues with fifteen leading philosophers (pp. 110-124). Oxford: Oxford University Press.

Wittgenstein, L. (1953). Philosophical investigations. Anscombe (trans.), Upper Saddle River, NJ.: Blackwell Publishers and Prentice-Hall, Inc.

Yablo, S. (2012). Explanation, extrapolation, and existence. Mind, 121(484), 1007-1029.

Yablo, S. (2014). Aboutness. Princeton NJ: Princeton University Press. 